\title{
Working
}

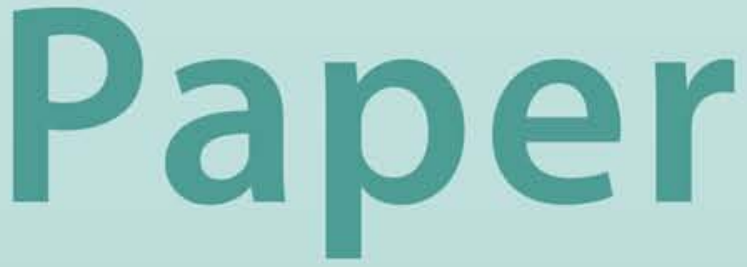


Argentina: Macroeconomic Crisis and Household Vulnerability

Ana Corbacho, Mercedes Garcia-Escribano, and

Gabriela Inchauste 


\title{
IMF Working Paper
}

\author{
Fiscal Affairs Department
}

\section{Argentina: Macroeconomic Crisis and Household Vulnerability}

\author{
Prepared by Ana Corbacho, Mercedes Garcia-Escribano, and Gabriela Inchauste ${ }^{1}$ \\ Authorized for distribution by Sanjeev Gupta
}

April 2003

\begin{abstract}
The views expressed in this Working Paper are those of the author(s) and do not necessarily represent those of the IMF or IMF policy. Working Papers describe research in progress by the author(s) and are published to elicit comments and to further debate.
\end{abstract}

Using urban household surveys, we constructed a panel dataset to study the effects of the Argentine macroeconomic crisis of 1999-2002 with the aim of (1) identifying the most vulnerable households, (2) investigating whether employment in the public sector and government spending served to decrease vulnerability, and (3) understanding the mechanisms used by households to smooth the effects of the crisis. Households whose heads were male, less educated, and employed in the construction sector were more vulnerable to the crisis, experiencing larger-than-average declines in income and higher dispersion. Households whose heads were employed in the public sector were more protected from the crisis, although higher public spending did not serve to decrease their vulnerability. A significant source of vulnerability was linked to changes in employment status, and we studied the determinants of the probability of being unemployed and of becoming unemployed. Last, we found that households were unable to perfectly smooth income shocks. Given these results, there is room for broadening social safety nets, particularly in the form of public works programs.

JEL Classification Numbers:H53, I31

Keywords: Argentina; macroeconomic crisis; household welfare

Authors’ E-Mail Address:acorbacho@imf.org; mgarciae@midway.uchicago.edu; minchauste@imf.org

\footnotetext{
${ }^{1}$ The authors would like to thank Sanjeev Gupta, Robert Gillingham, Emmanuel Jimenez, and participants at a conference at the Fiscal Affairs Department for useful comments and suggestions on earlier versions of this paper.
} 


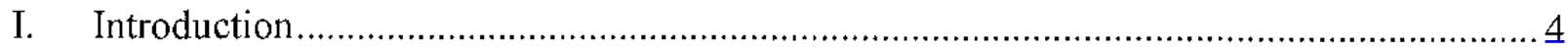

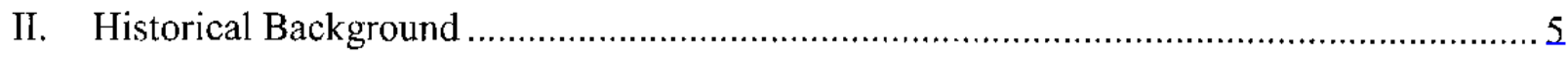

III. Description of the Data and Summary Statistics ...................................................... 7

A. The Argentine Permanent Household Survey ................................................... 7

B. Descriptive Statistics of the Panel Sample ........................................................... 8

IV. Who Bore the Burden of the Crisis? .................................................................... 12

A. Evidence on Heterogeneous Household Vulnerability to the Argentine Crisis........ 12

B. Most Vulnerable Socioeconomic Groups ....................................................... 15

C. The Role of Government Expenditures.......................................................... 19

D. Transmission Channels of Macro Shocks to Individuals: Employment Status ........ 20

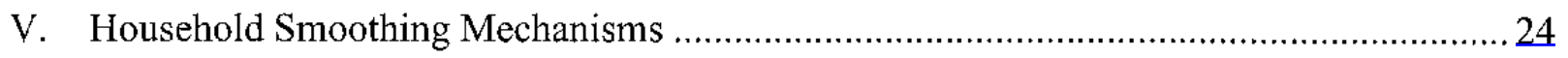

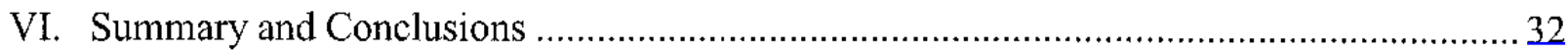

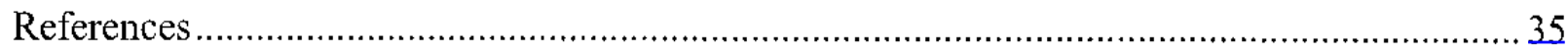

Tables

1. Descriptive Statistics of the Panel Sample

(a) Characteristics of the Head of Household ................................................................ 9

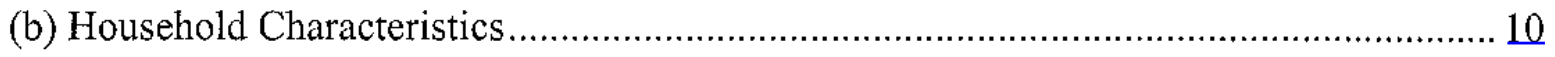

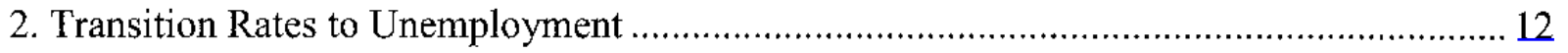

3. Average Individual Income, by Deciles................................................................ 13

4. Evolution of the Gini Coefficient for Household and Individual Income ......................... 13

5. By Regions, Evolution of Poverty ...................................................................... 14

6. Movements Across Income Quintiles ....................................................................... 15

7. Selected Regression Rules: Vulnerable Socioeconomic Groups .................................... 16

8. Selected Regression Results: The Effects of Government Spending .............................. 21

9. Selected Logit Regression Results ....................................................................... 23

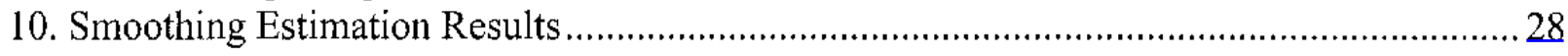

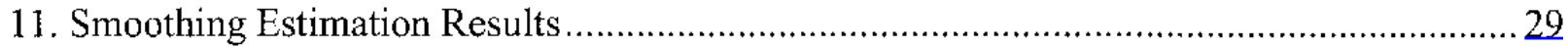

12. Smoothing Estimation Results-Change in the Logarithms Specification: Average Household vs. Extreme Poor Households .................................................................. 30

Figures

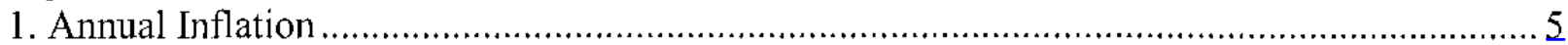

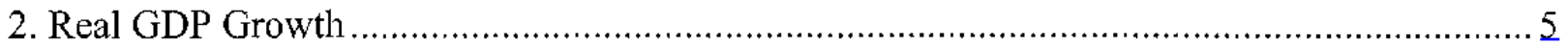

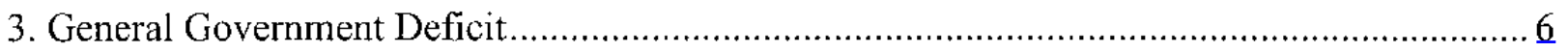

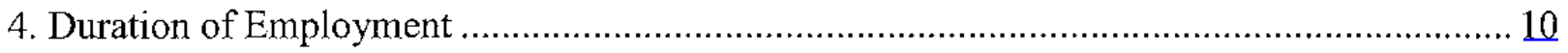


5. Unemployment and Underemployment Rates...................................................... 11

6. Evolution of Poverty in Greater Buenos Aires ............................................................... 14

7. Functional Classification of Provincial Government Spending ........................................19

8. Economic Classification of Provincial Spending ....................................................19

Text Box

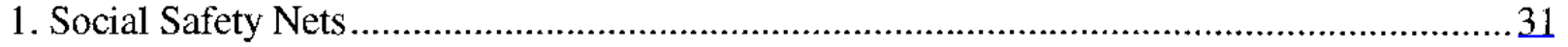




\section{INTRODUCTION}

Macroeconomic shocks can have significant effects on the welfare of individual households. Shocks at the macro level can be transmitted to households through numerous channels, including changes in domestic prices, the real exchange rate, and employment. Macro shocks leading to higher domestic inflation can have a relatively large impact on the poor, given that they often lack real assets to hedge against inflation and their wages are defined in nominal terms, translating into declines in the real purchasing power of their income. A real exchange rate depreciation may have a favorable impact on households employed in the tradable sector, but can hurt those employed in the production of nontradables through, for instance, fewer investment opportunities and lower demand for labor. This may be particularly relevant for urban households. The labor market can play a crucial role in transmitting macroeconomic shocks especially to the most vulnerable, as they are likely to derive a larger share of their income from employment. ${ }^{2}$ Rigidities in the labor market can amplify the effects of macroeconomic shocks. If real wages are inflexible downwards, macro shocks that negatively affect labor demand are absorbed through higher unemployment, underemployment, and informal sector employment, and can lead to increased employment volatility.

This paper addresses the effects of the macroeconomic crisis on household welfare in Argentina during 1999-2002. We focus primarily on the effects of the macroeconomic shock on the labor market, leading to income and employment fluctuations at the household level. Using survey panel data for 28 urban centers, we identify those characteristics that contributed the most to household and individual vulnerability. We also investigate whether employment in the public sector and government spending served as mitigating factors on the shocks transmitted to the household. This research should be especially useful in the design of appropriate and targeted social safety nets to alleviate the effects of the crisis on the poorest groups. In our discussion, we concentrate on four specific questions: (1) Who bore the cost of adjustment during the crisis and was the main channel of adjustment through wages or employment? (2) Were households with members employed in the public sector less vulnerable to the crisis? (3) Were households living in provinces with higher public spending more protected from adverse shocks? (4) What were the coping mechanisms used by households to diversify and hedge against the crisis? The remainder of the paper is organized as follows: Section $\Pi$ presents a brief historical background, and Section III describes the data and summary statistics. Section IV discusses the empirical strategy and estimation results, identifying those household characteristics more correlated with income and employment shocks and studying the role of the public sector. Section $\mathrm{V}$ analyzes mechanisms used by households to smooth the effects of the crisis, and offers some insight into the need for better design and targeting of social safety nets. Section VI concludes.

\footnotetext{
${ }^{2}$ See Agénor (2002) on the effects of macroeconomic policies on poverty, focusing on transmission channels through the labor market.
} 


\section{HistoricAi BACKGROUND}

In 1991, Argentina introduced the Convertibility Plan, after nearly three decades of chronic inflation. ${ }^{3}$ After two large hyperinflations in 1989 and 1990 , a currency board was adopted, pegging the peso to the dollar at a one-to-one rate. The currency board was successful in controlling inflation: for the twelve months after the adoption of the Convertibility Plan, annual inflation fell to 25 percent, and by the end of 1993, inflation was close to 10 percent. After 1993, inflation in Argentina was less than 5 percent, and there were even deflationary periods (Figure 1).

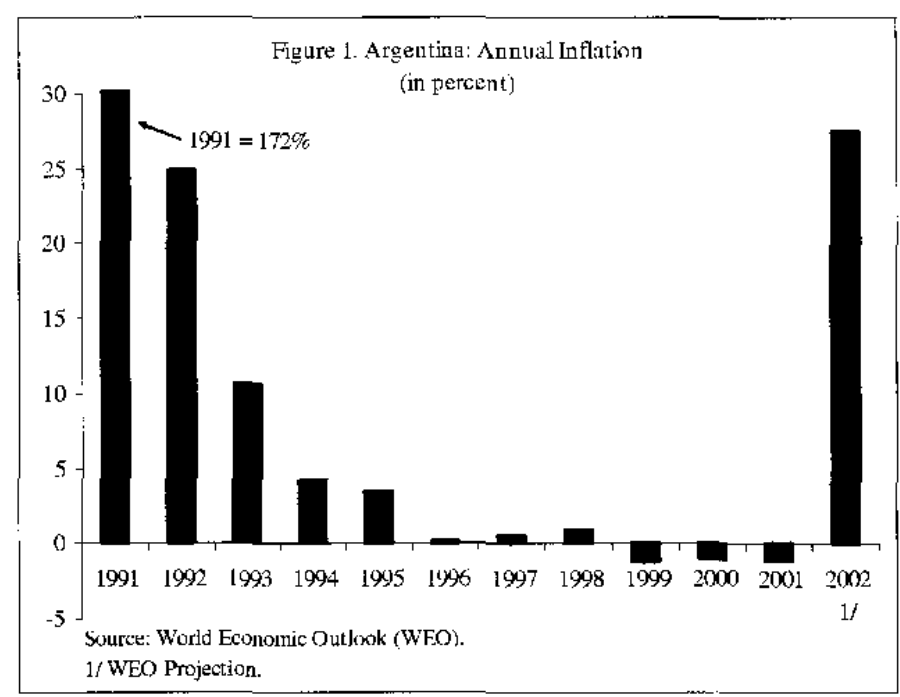

The adoption of the currency board marked the beginning of a prosperous period in terms of economic growth and low inflation. ${ }^{4}$ In addition to the new currency system, there were several structural reforms, including privatization of public enterprises, deregulation, and the opening of the economy.

Improvements in the fiscal area included simplification and streamlining of the tax system, improvements in tax administration, and greater control on expenditures. Real GDP growth averaged 8 percent per year between 1991 and 1994 (Figure 2). Capital inflows to the economy were large, leading to large domestic credit growth and a consumption and investment boom.

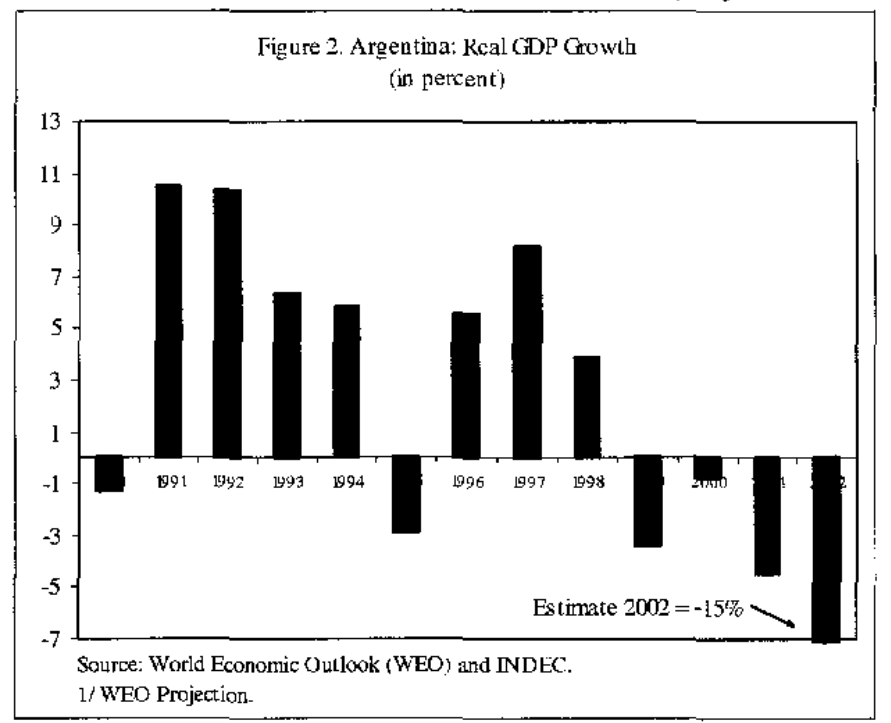

\footnotetext{
${ }^{3}$ Inflation has been a chronic problem in Argentina since the postwar period. Between 1960 and 1991, there were seven major stabilization programs that generally included a fixed exchange rate system and fiscal and monetary measures. See Choueiri and Kaminsky (1997) and Alvarez and Zeldes (2001) for a detailed chronology.

${ }^{4}$ Despite favorable macroeconomic indicators, Argentina's economy continued to face high structural volatility. See, for instance, Caballero (2000).
} 
After nearly a decade of good macroeconomic performance, Argentina's economy plunged into recession by end-1998. Argentina did not suffer during the Asian crisis in 1997, as real GDP grew by over 8 percent. However, economic growth started to decelerate during the second half of 1998 . There were several contributing factors. On the external front, these included (1) a deterioration in terms of trade; (2) a continuous appreciation of the real exchange rate, particularly after Brazil's devaluation in 1999; (3) a reversal of capital flows to emerging markets following Russia's default on its debt in 1998; and (4) the generalized "flight-to-quality" in all assets after the decline in NASDAQ in 2000. "

In addition to an unfavorable external environment, there were several internal factors that amplified the effects of external shocks. Fiscal deficits had been increasing since the adoption of the Convertibility Plan (Figure 3). Although the currency board regime put an end to bank financing, it provided no safeguard against excessive borrowing. In the event, fiscal performance was too weak throughout the $1990 \mathrm{~s}$ to prevent a growing reliance on private capital flows, resulting in

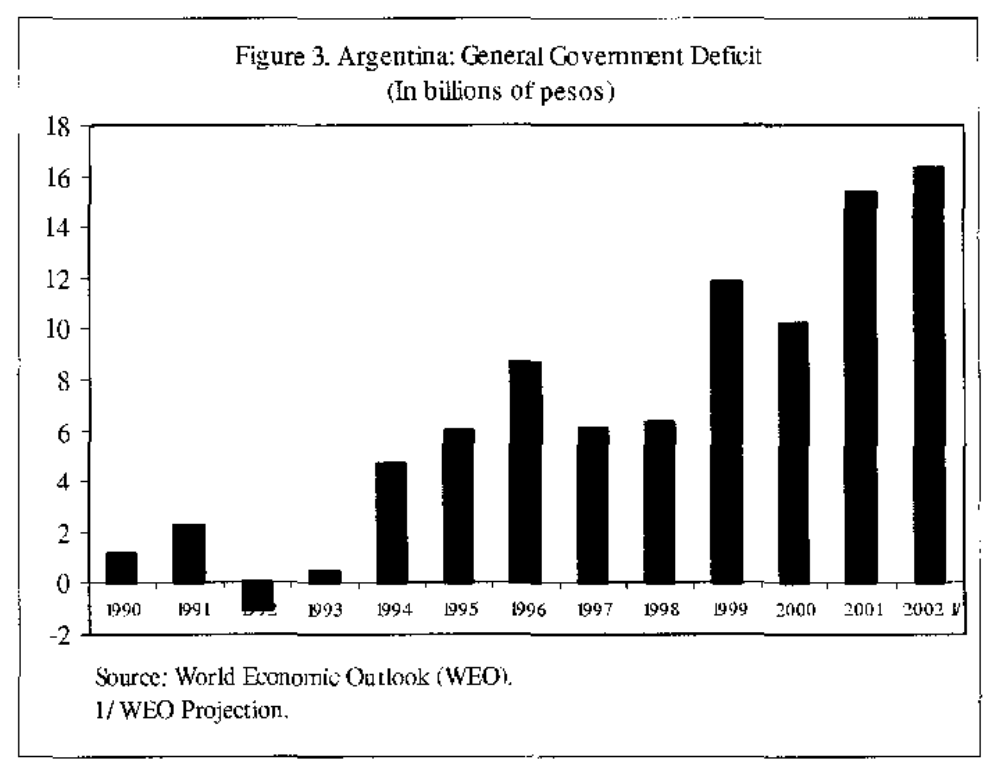
the accumulation of external debt throughout the period. ${ }^{6}$ By the end of 2000 , both domestic and international investors feared that Argentina would default on its debt. The spread on the yield of dollar-denominated bonds over similar U.S. Treasury bills, commonly referred to as "country risk," reached a record high, and the country lost access to external capital markets. Rigidities in the labor market contributed to increased unemployment and lower job security. ${ }^{7}$ On the political front, the De la Rua Administration faced serious constraints to implement fiscal adjustment measures. Additionally, the deterioration of social conditions and a freeze on bank deposits in 2001 contributed to widespread discontent and unrest in the population. After violent protests in end-December 2001, De la Rua resigned. A transitory government is in place until new presidential elections are held in 2003.

\footnotetext{
${ }^{5}$ See IMF (2001).

${ }^{6}$ See IMF (2002).

${ }^{7}$ See Llach and Llach (1998) for an analysis of the labor market in Argentina during the Convertibility Plan period.
} 
Argentina abandoned the fixed exchange rate in January 2002 in the midst of severe economic and political turmoil. By January 2003, the peso had depreciated by over 300 percent. Social indicators had been on a negative path since 1992, and deteriorated considerably after October 2001 . Poverty increased from 38.3 percent to 52.2 percent between October 2001 and May 2002; unemployment reached an alarming 21.4 perccnt in May $2002 ;{ }^{9}$ and income incquality, as measured by the Gini coefficient, ${ }^{10}$ had risen from 0.53 to 0.57 by May 2002 .

\section{Description of The Data AND Summary Statistics}

In this section, we describe the data used to analyze the effects of the crisis on household welfare. We also define the variables used in the study, and present summary statistics for the estimation sample.

\section{A. The Argentine Permanent Household Survey}

The empirical analysis is based on the Argentine Permanent Household Survey (Encuesta Permanente de Hogares, EPH) for the period 1999-2002. The National Statistical and Census Institute (INDEC) conducts the survey biannually in May and October in 28 urban centers. The EPH has a rolling unbalanced panel structure: once a household is chosen, it remains in the sample for four periods, that is, for a total of two years. The survey contains information at the household level, such as dwelling attributes and family composition, as well as at the individual level with demographic, labor market, and income data for each household member. Therefore, the behavior of individuals and the households in which they reside can be followed over time.

Some limitations of the data have implications for our study. First, the survey covers only urban areas. Our results should not be applied to rural households since these households might experience different income shocks and have access to different smoothing strategies. Second, consumption data are not available. Therefore, the ability of households to smooth consumption in the face of income shocks by saving/dissaving and borrowing/lending mechanisms cannot be determined. Finally, while some information on transfers, such as interhousehold transfers, provision of food, uncmployment insurance, severance payments, scholarships, and pensions is collected in the survey, other types of government interventions (including taxes) are not recorded. For this reason, our empirical strategy uses the EPH panel data to identify the socioeconomic groups vulnerable to the current economic shock; and macro-level data on public expenditures at the provincial level to evaluate if public programs

\footnotetext{
${ }^{8}$ Source: National Statistical and Census Institute (INDEC).

${ }^{9}$ Source: INDEC.

${ }^{10}$ Based on the distribution of individual income. Authors' calculations are based on the Permanent Household Survey. See Section III for further details.
} 
are being targeted to help these groups, or on the contrary, if such programs increase their vulnerability.

This paper follows the definition of "vulnerability" in Glewwe and Hall (1998): vulnerable groups are those that experience larger than average declines in socioeconomic status. Hence, vulnerability is a dynamic concept that focuses on changes in socioeconomic status. ${ }^{11}$ We use changes in pretax household income and its dispersion as our measure of the effect of the economic shock on household welfare.

\section{B. Descriptive Statistics of the Panel Sample}

Changes in household income and composition refer to a six-month period. The sample includes a total of 55,325 observations for 35,614 households. Households misreporting information for the head of household on any of the variables relevant for the empirical analysis are excluded. ${ }^{12,13}$ The distribution of the observations across the six subsamples and the descriptive statistics are shown in Table 1. Table la includes characteristics of the head of household, and Table $1 \mathrm{~b}$ shows characteristics of the household.

Table 1b indicates that living conditions, measured in terms of per capita household income, have deteriorated since May 1999, especially during the six months after October 2001. The average change in per capita household income is negative except for the subsample May 2000-October 2000. Note that the biggest decline in per capita household income occurred between October 2001 and May 2002.

\footnotetext{
${ }^{11}$ In contrast, poverty is a static concept since it concerns one's current socioeconomic status (Glewwe and Hall, 1998).

12 The head of household is defined as the household member between ages 15-64 with the highest reported income at the beginning of the six-month period. If no household member reports personal income, we designate as head of household the member that declares himself or herself as the decision maker.

${ }^{13}$ We excluded from the sample households with missing information on the education of the head of household, or with no information on any of the following variables for the head of household if employed: total hours worked and hourly earnings at the main occupation, years in that occupation, expected job duration (permanent, temporal, unknown), type of employer (public or private), or economic sector (primary, construction, manufacturing, services, and trade), if employed in the private sector; and type of worker (entrepreneur, self-employed, or wage worker), if employed in the private sector. Further, to minimize reporting errors, households with discrepancies on information on the gender of the head of household, with age declining over time, or with recorded hourly earnings-if working both periods-ten times larger or smaller than the amount recorded at the initial of the six-month period were excluded from the sample.
} 


\section{Table 1a. Descriptive Statistics of the Panel Sample}

Characteristics of the Head of Household 1/2/

\begin{tabular}{|c|c|c|c|c|c|c|}
\hline & $\begin{array}{c}\text { May } 99- \\
\text { Oct-99 }\end{array}$ & $\begin{array}{l}\text { Oct } 99- \\
\text { May-00 }\end{array}$ & $\begin{array}{c}\text { May 00- } \\
\text { Oct-00 }\end{array}$ & $\begin{array}{l}\text { Oct } 00- \\
\text { May-01 }\end{array}$ & $\begin{array}{c}\text { May } 01- \\
\text { Oct- }-1)\end{array}$ & $\begin{array}{l}\text { Oet 01- } \\
\text { May-02 }\end{array}$ \\
\hline Number of households & 11,066 & 9.279 & 9.701 & 9.155 & 9,458 & 6.666 \\
\hline \multirow[t]{2}{*}{ Schooling (years) } & 10.08 & 10.15 & 10.17 & 10.17 & 10.27 & 10.22 \\
\hline & $(4.28)$ & $(4.30)$ & $(4.30)$ & $(4.30)$ & $(4.30)$ & (4.31) \\
\hline \multirow[t]{2}{*}{ Age (years) } & 40.20 & 40.47 & 40.45 & 40.77 & 40.68 & 41.00 \\
\hline & $(11.74)$ & $(11.65)$ & $(11.74)$ & $(11.67)$ & $(11.69)$ & $(11.74)$ \\
\hline Male (percent) & 69.16 & 68.43 & 67.21 & 67.36 & 66.76 & 66.52 \\
\hline \multirow[t]{2}{*}{ If active, change in total personal income } & -27.26 & -37.75 & -27.35 & -40.87 & -50.60 & -159.86 \\
\hline & $(519.78)$ & $(476.06)$ & $(436.64)$ & $(428.48)$ & $(496.73)$ & $(362.12)$ \\
\hline \multicolumn{7}{|c|}{ If active, change in labor market status (percent) } \\
\hline Employed to unemployed & 4.54 & 5.96 & 4.89 & 6.07 & 6.31 & 8.84 \\
\hline Unemployed to employed & 2.69 & 3.01 & 3.31 & 3.45 & 3.25 & 3.41 \\
\hline Employed to employed & 90.88 & 88.95 & 89.07 & 88.24 & 87.07 & 83.48 \\
\hline Unemployed to unemployed & 1.90 & 2.08 & 2.73 & 2.23 & 3.37 & 4.27 \\
\hline \multicolumn{7}{|l|}{ If employed, type of employer (percent) $3 /$} \\
\hline Public & 26.15 & 26.21 & 27.01 & 27.48 & 27.62 & 27.16 \\
\hline Private & 73.85 & 73.79 & 72.99 & 72.52 & 72.38 & 72.84 \\
\hline \multicolumn{7}{|l|}{ If in private sector, type of work (percent) $3 /$} \\
\hline Owner / employer & 5.18 & 5.81 & 5.88 & 5.48 & 5.53 & 4.97 \\
\hline Self-employed & 26.16 & 26.46 & 26.11 & 27.03 & 26.70 & 28.62 \\
\hline Worker & 68.66 & 67.73 & 68.01 & 67.50 & 67.77 & 66.41 \\
\hline \multicolumn{7}{|c|}{ If in the private sector, economic sector (percent) $3 /$} \\
\hline Primary & 2.48 & 2.66 & 2.32 & 1.96 & 2.71 & 3.00 \\
\hline Construction & 16.06 & 15.29 & 14.44 & 14.41 & 13.90 & 13.57 \\
\hline Manufacturing & 17.48 & 16.65 & 16.30 & 16.20 & 15.87 & 16.81 \\
\hline Services & 44.47 & 45.26 & 46.08 & 47.37 & 47.32 & 47.27 \\
\hline Trade & 19.51 & 20.15 & 20.86 & 20.06 & 20.21 & 19.36 \\
\hline \multirow[t]{2}{*}{ If employed, years in that occupation $3 /$} & 8.46 & 8.48 & 8.45 & 8.76 & 8.76 & 8.93 \\
\hline & $(8.62)$ & $(8.55)$ & $(8.62)$ & $(8.78)$ & $(8.62)$ & $(8.79)$ \\
\hline \multicolumn{7}{|c|}{ If employed, expected job duration (percent) $3 /$} \\
\hline Permanent & 87.06 & 88.25 & 87.55 & 86.89 & 86.25 & 85.94 \\
\hline Temporal & 5.36 & 5.57 & 5.49 & 5.78 & 6.00 & 6.27 \\
\hline Unknown & 7.59 & 6.18 & 6.95 & 7.33 & 7.75 & 7.79 \\
\hline
\end{tabular}

Source: Authors' estimations. Panel data constructed using EPH from May 1999 to May 2002.

1/ Mean. Standard deviation in parenthesis.

$2 /$ Change refers to the change over the six-month interval period.

3 / Descriptive statistics at the beginning of the six-month interval period. 
Table 1b. Descriptive Statistics of the Panel Sample (cont.) Household Characteristics 1/ 2 /

\begin{tabular}{lcccccc}
\hline & $\begin{array}{c}\text { May 99- } \\
\text { Oct-99 }\end{array}$ & $\begin{array}{c}\text { Oct 99- } \\
\text { May-00 }\end{array}$ & $\begin{array}{c}\text { May 00- } \\
\text { Oct-00) }\end{array}$ & $\begin{array}{c}\text { Oct 00- } \\
\text { May-01 }\end{array}$ & $\begin{array}{c}\text { May 01- } \\
\text { Oct-01 }\end{array}$ & $\begin{array}{c}\text { Oct (01- } \\
\text { May-02 }\end{array}$ \\
\hline Region (percent) & & & & & & \\
$\quad$ Greater Buenos Aires & 13.92 & 14.84 & 14.89 & 15.50 & 14.47 & 18.59 \\
$\quad$ Northwest & 19.54 & 21.91 & 21.44 & 22.15 & 22.51 & 21.35 \\
$\quad$ Northeast & 13.26 & 12.42 & 12.18 & 12.34 & 12.52 & 11.61 \\
$\quad$ Cuyo & 14.26 & 7.21 & 8.14 & 8.13 & 8.41 & 10.19 \\
$\quad$ Pampeana & 26.83 & 29.55 & 29.14 & 28.84 & 27.78 & 24.65 \\
$\quad$ Patagonia & 12.20 & 14.07 & 14.20 & 13.04 & 14.32 & 13.62 \\
Change per capira household income & -0.82 & -3.59 & 3.65 & -4.99 & -11.32 & -64.61 \\
& $(242.08)$ & $(234.40)$ & $(230.38)$ & $(185.33)$ & $(232.10)$ & $(166.64)$ \\
Number of household members 3/ & 4.02 & 4.02 & 3.99 & 3.98 & 3.97 & 3.97 \\
& $(1.99)$ & $(1.98)$ & $(1.97)$ & $(1.99)$ & $(2.01)$ & $(2.06)$ \\
Proportion children 3/ & 0.24 & 0.24 & 0.24 & 0.24 & 0.23 & 0.23 \\
& $(0.24)$ & $(0.24)$ & $(0.24)$ & $(0.24)$ & $(0.24)$ & $(0.24)$ \\
Presence of elderly (percent) 3/ & 22.00 & 21.92 & 22.36 & 22.26 & 22.12 & 22.28 \\
Proportion working members 3/ & 0.36 & 0.36 & 0.35 & 0.36 & 0.36 & 0.35 \\
& $(0.24)$ & $(0.23)$ & $(0.23)$ & $(0.24)$ & $(0.24)$ & $(0.24)$ \\
Proportion unemployed members 3/ & 0.05 & 0.05 & 0.06 & 0.06 & 0.07 & 0.07 \\
& $(0.12)$ & $(0.13)$ & $(0.14)$ & $(0.13)$ & $(0.14)$ & $(0.14)$ \\
\hline
\end{tabular}

Source: Authors' estimations. Panel data constructed using EPH from May 1999 to May 2002.

1/ Mean. Standard deviation in parenthesis.

2/ Change refers to the change over the six-month interval period.

3 / Descriptive statistics at the beginning of the six-month interval period.

The decline in per capita household income was associated mainly with a drop in the total income of the head of household, and more precisely from the decline in the household head's earnings-the main source of household income (Table 1a). The main reasons for the decline in the head of household's earnings were an increase in unemployment, and a striking decline in the earnings of those employed. Rates for transition

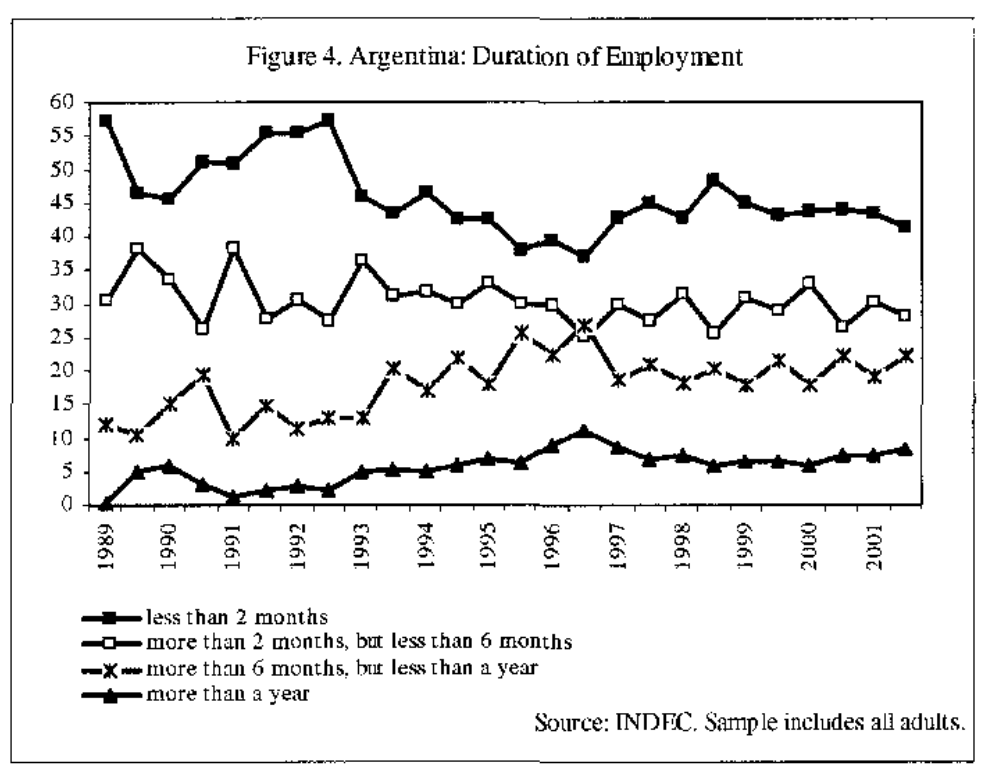


into unemployment rose remarkably; the number of household heads becoming unemployed rose from 4.75 percent between May 1999 and October 1999 to 9.57 percent between October 2001 and May 2002 (Table 2). At the same time, unemployment duration remained relatively constant (Figure 4). As a result, unemployment rates increased (Figure 5). The second source of the decline in the household head's earnings arose from a reduction in the number of hours worked, ${ }^{14}$ and from a slight decline in hourly earnings.

As a response to the economic shock, other household members increased their labor participation; the mean change in the proportion of inactive members is negative, but labor market conditions were not favorable to them either. Consequently, the proportion of unemployed members-excluding the head of household-rose (Table 1b).

Given our definition for the head of household, Table la shows that the evolution of labor market conditions in 1999-2002 was similar across

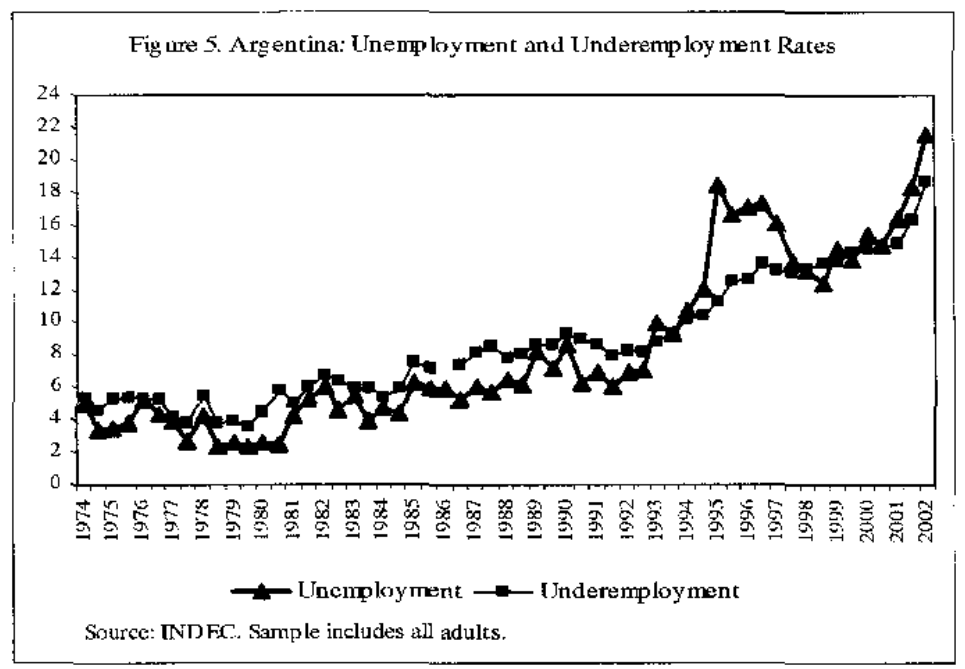
education groups. In particular, the number of years of schooling of the head rose; the number of female-headed households increased; the number of household heads employed in the public sector rose relative to employment in the private sector except for the period October 2001-May 2002; the number of household heads employed in the construction and manufacturing sectors declined, while those in the service sector rose; and household heads' years in the same occupation rose. The proportion of self-employed workers rose, while the proportion of wage workers fell; this probably indicates also an expansion of informal-sector employment, and, therefore, the lack of a social protection scheme for the labor force.

Similar conclusions are drawn from the descriptive statistics on adult characteristics (Table 1b). The probability of becoming unemployed rose from 5.63 percent for the sample May 1999-October 1999 to 11.40 percent for the sample October 2001-May 2002 (Table 2). Last, consistent with the household traits commented on earlier, adult labor force participation rates increased (the transition from inactive to active individuals was 15.53 percent in May 1999-October 1999 and 19.56 percent in October 2001-May 2002).

\footnotetext{
${ }^{14}$ Underemployment rates increased throughout the period. Underemployment refers to the percentage of occupied adults in the active population working less than 35 hours per week for involuntary reasons.
} 
Table 2. Transition Rates to Unemployment

\begin{tabular}{lrrrrrr}
\hline & May 99 & Oct 99- & May 00- & Oct 00- & May 01 & Oct 01- \\
& Oct 99 & May 00 & Oc -00 & May 01 & Oct 01 & May 02 \\
\hline Employed heads at $t$ if cmployed at $t-1$ & 95.25 & 93.72 & 94.79 & 93.56 & 93.24 & 90.43 \\
Unemployed heads at $t$ if employed at $t-1$ & 4.75 & 6.28 & 5.21 & 6.44 & 6.76 & 9.57 \\
Employed adults at $t$ if employed at $t-1$ & 94.37 & 92.3 & 93.77 & 92.01 & 91.62 & 88.6 \\
Unemployed adults at $t$ if employed at $t-1$ & 5.63 & 7.7 & 6.23 & 7.99 & 8.38 & 11.4 \\
\hline
\end{tabular}

Source: Authors' estimations. Panel data constructed using EPH from May 1999 to May 2002.

\section{Who Bore the Burden of the Crisis?}

In this section of the paper, we discuss which socioeconomic groups in the population disproportionately bore the burden of the adjustment during the macroeconomic crisis. First, we present evidence on household vulnerability. Second, using panel regression analysis, we identify which socioeconomic groups were affected the most by the crisis in Argentina. Then, we focus on the labor market as a transmission channel of macroeconomic shocks to households and analyze the effects on employment. Last, we examine mechanisms households relied on to smooth those shocks.

\section{A. Evidence on Heterogeneous Household Vulnerability to the Argentine Crisis}

It stands to reason that households are not affected equally by macroeconomic shocks, such as economic crises or adjustment programs. However, little research has been done to identify the socioeconomic groups most vulnerable to macro shocks, and the reasons why these groups suffer the most. Until recently, the required data did not exist; in contrast to economic aggregates, micro-level data on household expenditures or income allows a deeper exploration of the social implications of adverse macroeconomic events. Examples of this line of research are Glewwe and Hall (1994 and 1998) for Peru, Eble and Koeva (2002) for Russia, and Frankenberg, Thomas, and Beegle (1999) for Indonesia. In this paper, by exploiting the pancl structure of microeconomic data for Argentina, we will apply similar methodologies to quantify the effects of the macroeconomic crisis on household vulnerability.

Average per capita household income declined throughout the period 1999-2002, but more so after October 2001. The average household experienced a decline of 3.8 percent in per capita household income between May 1999 and October 2001. Household income then collapsed by 23.8 percent between October 2001 and May 2002 (Table 3). Individuals in the poorest decile of the income distribution experienced the largest declines in personal income. This result was even more pronounced during the period October 2001-May 2002 (Table 3), when per capita household income of the poorest decile collapsed by 41 percent, compared to a 23 percent decline in the per capita household income of the richest decilc, indicating that the relative vulnerability of poorest groups increased during the peak of the crisis. Individuals 
in the wealthiest decile were less affected by the economic shock than the poor, but also experienced significantly larger declines in income after October 2001.

Table 3. Average Per Capita Household Income, by Deciles

Average Individual Income, by Deciles

\begin{tabular}{|c|c|c|c|c|c|c|c|c|c|c|}
\hline \multirow[b]{3}{*}{ Decile } & \multicolumn{5}{|c|}{ Per Capita Household Income } & \multicolumn{5}{|c|}{ Active Adult Income } \\
\hline & \multirow[b]{2}{*}{ May-99 } & \multirow[b]{2}{*}{ Oct-01 } & \multirow[b]{2}{*}{ May-02 } & \multicolumn{2}{|c|}{ Percentage Change } & \multirow[b]{2}{*}{ May-99 } & \multirow[b]{2}{*}{ Oct-01 } & \multirow[b]{2}{*}{ May-02 } & \multicolumn{2}{|c|}{ Percentage Change } \\
\hline & & & & $\begin{array}{c}\text { May 99 - } \\
\text { Oct 01 }\end{array}$ & $\begin{array}{l}\text { Oct } 01- \\
\text { May } 02\end{array}$ & & & & $\begin{array}{c}\text { May } 99- \\
\text { Oct } 01\end{array}$ & $\begin{array}{l}\text { Ocl 01- } \\
\text { May 02 }\end{array}$ \\
\hline 1 & 32.0 & 20.4 & 11.9 & -36.3 & -41.7 & 0.0 & 0.0 & 0.0 & - & \\
\hline 2 & 71.0 & 56.9 & 37.4 & -19.9 & -34.3 & 111.3 & 70.4 & 22.8 & -36.7 & -67.7 \\
\hline 3 & 98.7 & 89.3 & 60.0 & -9.5 & -32.8 & 215.3 & 173.4 & 73.9 & -19.5 & -57.4 \\
\hline 4 & 132.6 & 119.5 & 85.2 & -9.9 & -28.7 & 291.6 & 246.6 & 146.7 & -15.4 & -40.5 \\
\hline 5 & 168.6 & 151.3 & 115.0 & -10.3 & -24.0 & 371.3 & 316.2 & 233.7 & -14.8 & -26.1 \\
\hline 6 & 206.8 & 195.5 & 153.6 & -5.5 & -21.4 & 439.0 & 399.7 & 287.8 & -9.0 & -28.0 \\
\hline 7 & 266.2 & 253.8 & 195.9 & -4.7 & -22.8 & 535.2 & 485.8 & 348.8 & -9.2 & -28.2 \\
\hline 8 & 351.8 & 333.9 & 256.6 & -5.1 & -23.1 & 687.1 & 634.1 & 458.8 & -7.7 & -27.6 \\
\hline 9 & 494.6 & 489.5 & 368.2 & $-1,0$ & -24.8 & 901.8 & 894.7 & 645.1 & -0.8 & -27.9 \\
\hline 10 & 1073.6 & 1054.2 & 808.1 & -1.8 & -23.3 & 1920.6 & 1832.2 & 1354.0 & -4.6 & -26.1 \\
\hline Total & 282.5 & 271.8 & 207.2 & -3.8 & -23.8 & 531.6 & 474.9 & 343.5 & -10.7 & -27.7 \\
\hline
\end{tabular}

Source: Authors' estimations. Panel data constructed using EPH from May 1999 to May 2002.

Note: Monthly per capita household income. Values are in 1999 pesos.

Active adults, including head of household.

As a result, the distributions of household and individual income were more unequal at the end of the period under study than in May 1999. Gini coefficients were computed for each of the six subsamples at the beginning and at the end of the six-month period to evaluate the evolution of inequality across individuals and across households (Table 4).

Table 4. Evolution of the Gini Coefficient for Household and Individual Income

\begin{tabular}{llcccccc}
\hline & & May 99- & Oct 99- & May 00- & Oct 00- & May 01- & Oct 01- \\
& & Oct 99 & May 00 & Oct 00 & May 01 & Oct 01 & May 02 \\
\hline Per capita household income & Initial & 0.50 & 0.49 & 0.50 & 0.50 & 0.52 & 0.52 \\
& Final & 0.49 & 0.50 & 0.51 & 0.50 & 0.52 & 0.53 \\
\multirow{3}{*}{ Active adult individual income } & Initial & 0.49 & 0.49 & 0.51 & 0.51 & 0.52 & 0.53 \\
& Final & 0.50 & 0.51 & 0.52 & 0.52 & 0.54 & 0.57 \\
\hline
\end{tabular}

Source: Authors' estimations. Panel data constructed using EPH from May 1999 to May 2002.

The percentage of population under the poverty line in greater Buenos Aires has steadily increased since $1994,{ }^{15}$ but even more so since the start of the economic crisis in 1999 and particularly since October 2001 (Figure 6). Also, the proportion of poor

\footnotetext{
${ }^{15}$ Poverty is measured as the percentage of households under the poverty line. Lengthy time series for regions other than greater Buenos Aires are not available.
} 
persons exceeds that of poor households, implying that poor households have more members. Indeed, change in household size is one of the mechanisms households rely on to insulate households' welfare from shocks to personal labor income. The percentage of population under the poverty line significantly increased in other regions as well. In May 2002, poverty reached levels over 60 percent in the Northeastern and Northwestern regions, but was below 40 percent in Patagonia (Table 5).

Exploiting the panel structure of our data set, Table 6 presents the movements across per capita household income quintiles and individual income quintiles for each of the subsamples. As a result of differences in how hard

Figure 6. Argentina: Evolution of Poverty in Greater Buenos Aires

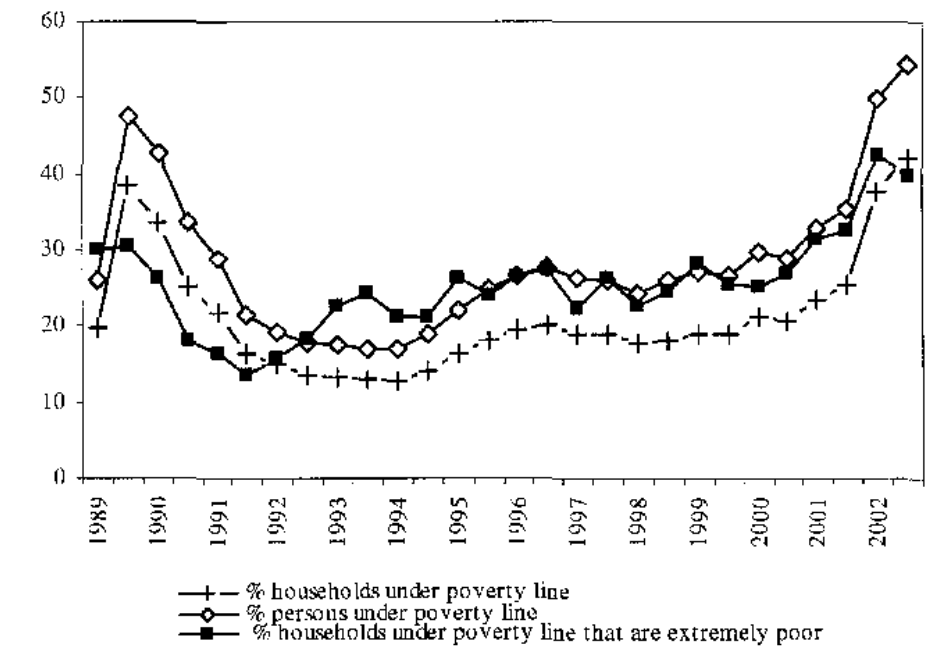

Source: Sistema de Información, Monitoreo y Evaluación de Progranas Sociales (SIEMPRO)

households were hit by the macroeconomic shock and in their ability to smooth those shocks, a large number of households moved into a different quintile, especially during the last period. The share of active adults that shifted quintiles was even larger, indicating that significant changes occurred within the household.

Table 5. By Regions, Evolution of Poverty

\begin{tabular}{|c|c|c|c|c|c|c|c|c|}
\hline & \multicolumn{3}{|c|}{ Households 1/ } & \multirow{2}{*}{$\begin{array}{c}\text { Percentage } \\
\text { change } \\
\text { Oct } 01 \text {-May } \\
02\end{array}$} & \multicolumn{3}{|c|}{ Persons 2/ } & \multirow{2}{*}{$\begin{array}{c}\text { Percentage } \\
\text { change } \\
\text { Oct } 01-\text { May } \\
02\end{array}$} \\
\hline & May-01 & Oct-01 & May-02 & & May-0I & Oct-01 & May-02 & \\
\hline Total & 26.20 & 28.00 & 41.4 & 0.48 & 35.90 & 38.30 & 53.00 & 0.38 \\
\hline Cuyo & 29.30 & 30.30 & 44.9 & 0.48 & 38.60 & 39.60 & 54.90 & 0.39 \\
\hline Greater Buenos Aires & 23.50 & 25.50 & 37.7 & 0.48 & 32.70 & 35.40 & 49.70 & 0.40 \\
\hline Northeast & 44.00 & 45.51 & 59.4 & 0.31 & 56.60 & 57.20 & 69.80 & 0.22 \\
\hline Northwest & 37.10 & 37.90 & 53.0 & 0.40 & 47.50 & 48.30 & 63.50 & 0.31 \\
\hline Pampeana & 24.70 & 27.20 & 41.8 & 0.54 & 33.80 & 37.10 & 52.70 & 0.42 \\
\hline Patagonia & 18.10 & 18.00 & 30.9 & 0.72 & 23.90 & 23.20 & 39.10 & 0.69 \\
\hline
\end{tabular}

Source: INDEC.

1/ Households in poverty measured as percentage of household under poverty line.

2/ Persons in poverty measured as percentage of persons in the population under poverty line. 
Table 6. Movements Across Income Quintiles

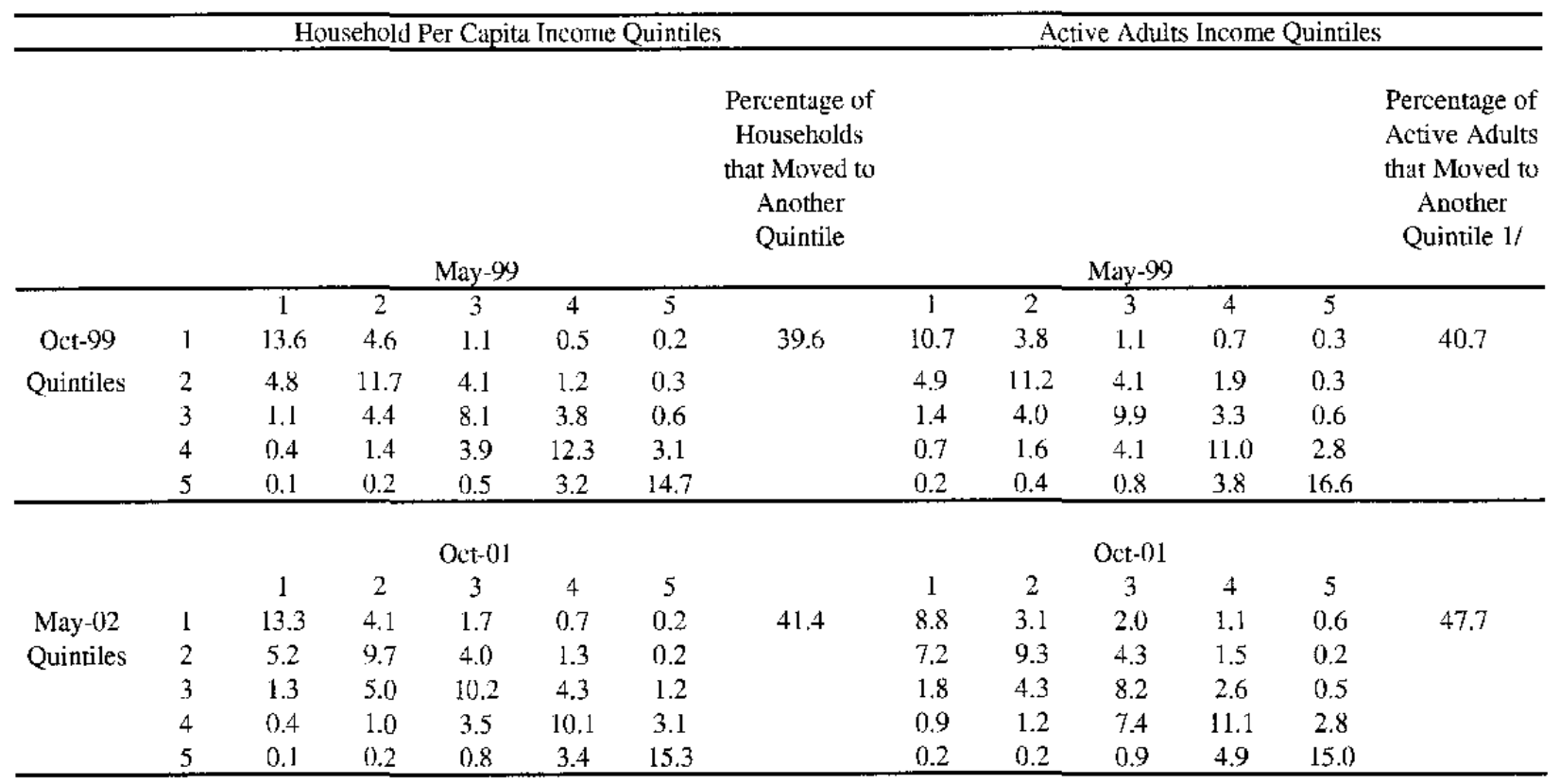

Source: Authors' estimations. Panel data constructed using EPH from May 1999 to May 2002.

1/ Adults, including head of household.

\section{B. Most Vulnerable Socioeconomic Groups}

This section analyzes the determinants of changes in income and draws inferences regarding socioeconomic characteristics and vulnerability. The test consists in regressing vulnerability measured by the difference in the logarithm of household income

$d L H Y_{h, r, t}=\log \left(\frac{\text { Yhousehold }_{h, r, t}}{\text { Yhousehold }_{h, r, t-1}}\right)$ on a vector of characteristics of the head of household, $x_{h, r, t-1}$; and a vector of household characteristics, $w_{h, r, t-1, \text {; }}$ plus time dummies, $\alpha_{t-1, t ;}$; region dummies, $\delta_{;}$; and a constant term, $\gamma$. The subscript $h$ indexes households; $r$ indexes geographical region; and $t$ indexes time. Household welfare is measured as the logarithm of total household income, Yhousehold. Interaction terms of the characteristics with the year dummy $\alpha_{O \text { ctober } 1, \text { May } 02}$ are included to test for differences in the beta coefficients for the period October 2001 and May 2002 during the peak of the crisis. We have estimated equation (1) using a random effects specification for the error term:

$$
\begin{aligned}
\log \left(\frac{\text { Yhousehold }_{h, r, t}}{\text { Yhousehold }_{h, r, t-1}}\right) & =\gamma+\alpha_{t-1, t}+\delta_{r}+\beta^{1} \cdot x_{h, r, t-1}+\alpha_{\text {October } 01, \text { May } 2002} \cdot \widetilde{\beta}^{1} \cdot x_{h, r, t-1}+ \\
& +\beta^{2} \cdot w_{h, r, t-1}+\alpha_{\text {ectober } 01, M a y 02} \cdot \widetilde{\beta}^{2} \cdot w_{h, r, t-1}+\varepsilon_{h, r, t}
\end{aligned}
$$




\section{Table 7: Selected Regression Results: Vulnerable Socioeconomic Groups 1/}

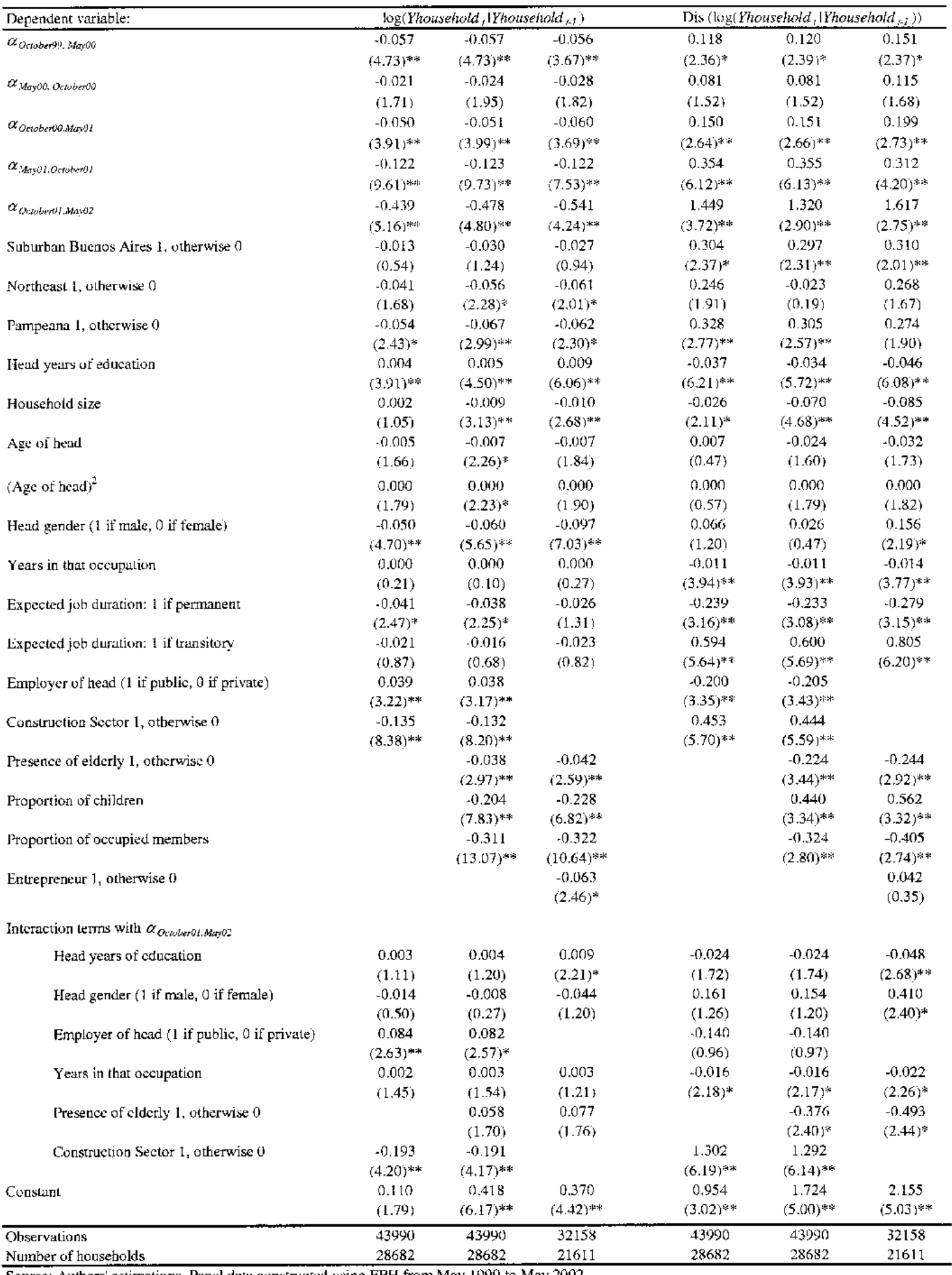

Source: Authors' estimations. Panel data coustructed using EPH from May 1999 to May 2002.

Note: T-statistics in parentheses; * significant at $5 \%$; ** significant at $1 \%$.

$1 /$ Complete tegression results are available upon request. Regressions include dummies for all regions, a dummy for calegory worker, dumnies for primary, manufacturing and trade sectors, and interaction terms with all variables and the period October 2001-May 2002.

The excluded dummies are: tine durnmy: May99-October99; expected job duration: unknown; region: city of Buenos Aires;

type of work in the private sector: sclf-employed; and economic sector: service sector. 
A household with a certain socioeconomic trait is more (less) vulnerable when the beta coefficicnt for that particular trait is negative (positive). Since the time and region dummies $\alpha_{i}$ and $\delta_{r}$ control for economy-wide shocks, or uninsurable shocks, a negative (positive) beta coefficient indicates that the group with this characteristic experienced a decline in welfare larger (smaller) than the average, holding all other characteristics constant.

In addition to measuring differential vulnerability among socioeconomic groups, we tested for variations in vulncrability within groups. It could be the case that on average, households with a particular trait do better than others during the crisis, but still inequality across households with that trait might increase. To capture whether there is a relationship between traits and changes in inequality, we used the specification (1) but replaced the dependent variable by the dispersion of the difference in the logarithm of household income:

$\operatorname{Dis}_{h, r, t}=\left(d L H Y_{h, r, t}-\text { mean }\left(d L H Y_{h, r, t}\right)\right)^{2}$, where Dis is defined for household $h$ in region $r$, at time $t$, and mean $(d L H Y)$ is the mean of the difference in the logarithm of household income.

Table 7 presents the coefficients and t-statistics from these regressions. Only the most significant results are shown. The vector of traits of the head of household includes years of education, age, age squared, gender, type of employer (private or public, if employed), working experience measured as the number of years in that occupation, expected job duration (permanent, temporal, or unknown), economic sector for those working in the private sector (primary, construction, manufacturing, services, trade, or other); and type of worker for those working in the private sector (entrepreneur, self-employed, or worker). Household traits included are household size, presence of elderly people, proportion of children, and proportion of employed household members. The first two columns of each regression present results for the whole sample, while the third and sixth columns correspond to households whose head was employed in the private sector. ${ }^{16}$

Household welfare deteriorated from the beginning of the period, with the biggest decline in October 2001-May 2002. In addition, inequality across households also increased remarkably, especially after October 2001. Regional dummies capture differences in the magnitude of the economic shock among regions. The Northeast and Pampeana regions experienced larger declines in welfare, while the city of Buenos Aires experienced the smallest.

\footnotetext{
${ }^{16}$ In order to control for initial poverty levels that could lead to a bias in the estimated coefficients, an initial wealth variable was added identifying households in extreme poverty in the initial period. Houscholds in extreme poverty were defined by housing characteristics provided in the EPH survey. We identified the poorest households as those that were living in a house with no running water, no electricity, no private bathroom, or made with construction materials inferior to the typical brick and stucco. The resulting estimates were not substantially different from the results reported below. Households initially classified as extremely poor were more vulnerable, although this variable becomes less significant when the interaction term with the dummy for the period of October 2001-May 2002 is included.
} 
Households with better-educated heads were less vulnerable. In addition to time and regional dummies, head of households' traits help explain changes in income levels. On average and holding other traits constant, households headed by individuals with more education were less susceptible to the changing economic conditions. Households whose head was more educated experienced smaller declines in income (or larger increases) of about 0.5 percent per extra year of education. Inequality across households with bettereducated heads was also lower. Dispersion of household income was about 3 percent lower per extra year of education. Inequality across households with better-educated heads declined even further during the last period under analysis, particularly for those employed in the private sector.

With respect to gender of the head of household, the average decline in income of maleheaded households was larger, ceteris paribus, than that of female-headed households. Male-headed households experienced a 6 percent larger decline in income (or smaller increase) than female-headed households. Results also suggest that dispersion was higher for those households headed by males employed in the private sector, especially after October 2001 (last column, Table 7).

Households whose head was employed in the public sector were less vulnerable to the economic shock. Results suggest that households headed by public sector employees experienced nearly a 4 percent smaller decline in income than households headed by private sector employees, and this difference increased to about 12 percent between October 2001 and May 2002. Also, dispersion in living standards was lower when compared to dispersion of households whose head was employed in the private sector. Within the private sector, households whose head was employed in construction were more vulnerable to the economic conditions as they experienced a 13 percent larger decline in their income than those whose head was employed in the services sector. In addition, inequality in household welfare within the construction sector widened, especially after October 2001 . When looking at the regressions for households whose head was employed in the private sector only (Column 3), we find that, on average, households whose head was an entrepreneur experienced larger declines in income than households whose head was a wage worker or self-employed. Results relative to the occupation of the head of household are robust to variables controlling for working experience and expected job duration.

With respect to household characteristics, the coefficient for household size indicates that total household income declined less for smaller households. Results show that larger households experienced larger declines in income of 0.9 percent per extra household member. This result might capture the fact that poor households, which are characterized by larger families, are on average more vulnerable. Dispersion in income growth across was smaller for large households, suggesting smaller variation in how well these households are able to cope with shocks.

Households with a larger share of employed members experienced a higher decline in incomes, but lower dispersion. Given that the macroeconomic shock mostly affected labor 
income, households deriving most of their income from the labor market were affected more than households who potentially derived their income from other sources.

Similarly, households with elderly members experienced larger declines in their income, while dispersion within these families fell, potentially as a result of social security transfers.

Last, households with a higher proportion of children experienced a larger decline in income than the average. In addition, dispersion in income rose for these households. Both results agree with the intuition that households with more children are more vulnerable.

\section{The Role of Government Expenditures}

Provincial government spending, roughly 40 percent of consolidated government spending, remained fairly constant during 1998-2001, with some marginal increase in 2001. As shown in Figure 7, the largest share of spending is allocated to the social sector, which includes mainly health, education, social insurance, social assistance, and urban development. With regard to the economic classification of expenditures, the bulk of spending is allocated to wages (Figure 8).

Results suggest that higher government spending did not protect household welfare, and, in fact, may have contributed to its decline. The lack of detailed data on access to public transfers and social programs at the household level limits our analysis to studying the impact of aggregate provincial public spending on vulnerability. The $\log$ of provincial government spending per capita incurred in
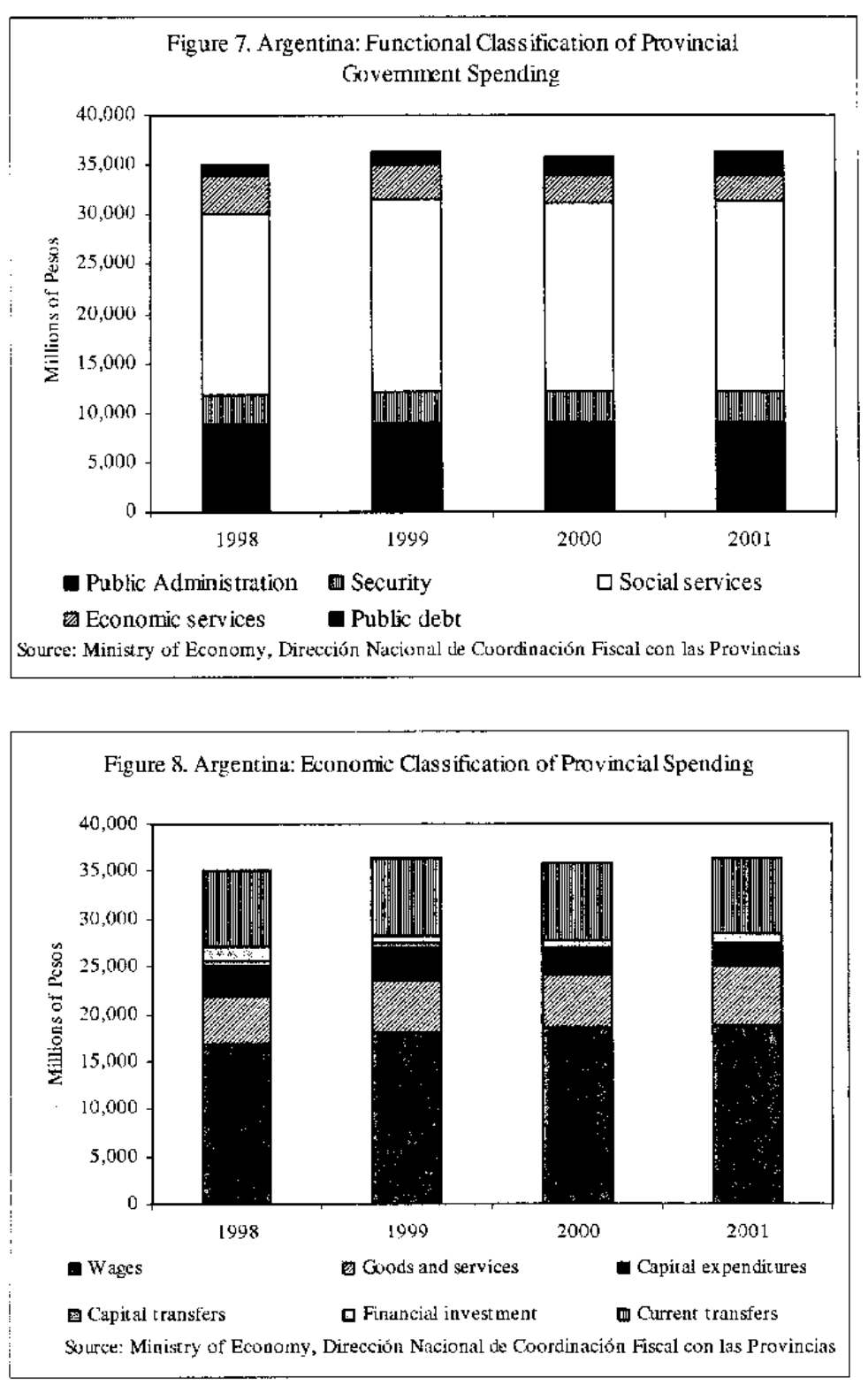
the previous year was included in the regressions above. As shown in Table 8, households in provinces with higher spending experienced a larger decline in their income levels of about 5 percent per additional percent of spending per capita. Additionally, dispersion across these households was larger. ${ }^{17}$

The results from disaggregating spending by economic classification suggest that households in provinces that had spent more on wages and salaries fared worse, while households in provinces that had spent more on capital expenditures were relatively better off. This is particularly interesting, implying that although households whose head was employed in the public sector suffered less than the average, as discussed in the previous section, higher spending on wages and salaries made the average households in those provinces worse off. Moreover, it could indicate that provinces investing in capital expenditures could have spurred growth leading to improvements in household welfare and a decline in dispersion. Finally, results from disaggregating by functional classification show that social spending was not significant in its impact on household income changes, potentially pointing to its lack of effectiveness and poor targeting. ${ }^{18}$

\section{Transmission Channels of Macro Shocks to Individuals: Employment Status}

After having examined the determinants of changes in income at the household level, we study the determinants of changes on income at the individual level. We focus on labor income changes, and in particular, on the determinants of unemployment, since this is the main shock to personal income.

\footnotetext{
${ }^{17}$ To control for potential endogeneity, we estimated an IV model using lags of spending as instruments. The IV results were virtually identical when using $\log$ of total spending per capita. When using functional classification, the effects of debt service appear equally significant to the non-IV model, but the effects are somewhat larger. When using economic classification, results are not statistically significant, but coefficients go in the same direction with somewhat smaller sizes. In addition, the sensitivity of the results to the inclusion of provincial dummies was tested. Regressions including provincial dummies reduce the significance of the coefficients. However, the magnitudes of the estimated coefficients are larger with the same signs. Results of these regressions are available upon request.

${ }^{18}$ Bonari and Gasparini (2002) find that consolidated social spending in Argentina was generally progressive 1997-98, but do not comment on its effectiveness or targeting. This includes spending on social security, which is regressive, and spending in the social sectors, which is progressive. Within the social sectors, health, and social assistance are highly pro-poor, while education is slightly progressive. Spending on water, housing, and other services is regressive.
} 
Table 8: Selected Regression Results: The Effects of Government Spending 1/

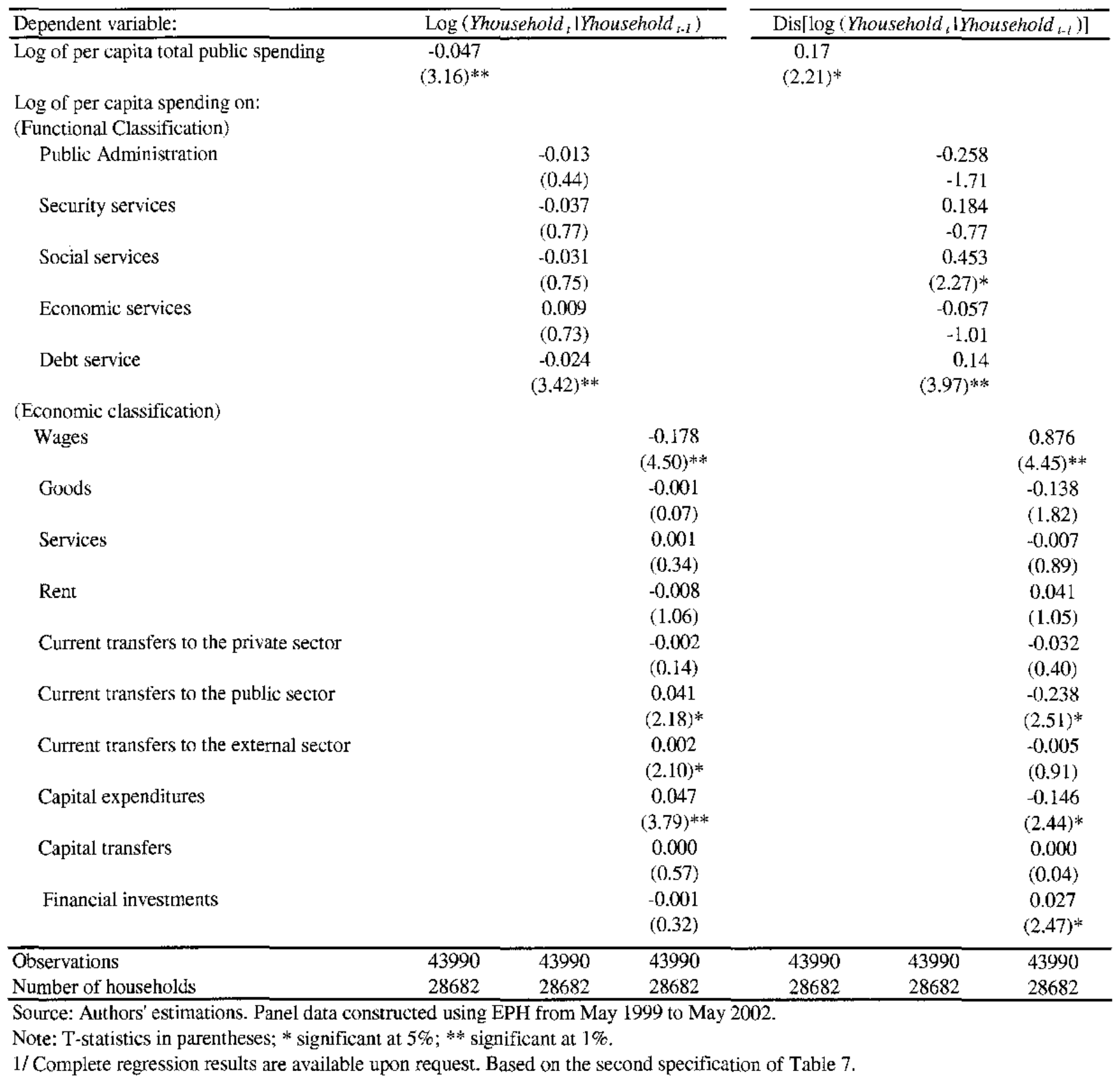


First, we investigate the relationship between individual characteristics and the employment status of each adult participating in the labor market. We model the probability of being unemployed as:

Unemployed $_{i, r, t}= \begin{cases}1 & \text { if } \gamma+\alpha_{t}+\delta_{r}+\beta \cdot z_{i, r, t}+\alpha_{\text {May } 2002} \cdot \widetilde{\beta} \cdot z_{i, r, t}+u_{i, r, t}>0 \\ 0 & \text { otherwise }\end{cases}$

where $\mathrm{z}_{\mathrm{i}, \mathrm{r} . \mathrm{t}}$ are individual characteristics and $\alpha_{\text {May2002 }}$ is a time dummy. We assume a random effects logit specification for the cumulative distribution function of $u$. The subscript $i$ indexes individuals; $r$ indexes geographical region; and $t$ indexes time.

Second, we focus on the susceptibility to changing economic conditions. To capture this dynamic concept, we model the transition into unemployment, that is, the probability of becoming unemployed conditioned on being employed at the initial period, as a function of initial individual traits:

Unemployed $_{i, r, t} /$ Employed $_{i, r, t-1}=\left\{\begin{array}{l}1 \text { if } \gamma+\alpha_{t-1, t}+\delta_{r}+\beta \cdot z_{i, r, t-1}+\alpha_{\text {October } 2001, \text { Mav2 2002 }} \cdot \widetilde{\beta} \cdot z_{i, r, t-1}+u_{i, r, t}>0 \\ 0 \text { otherwise }\end{array}\right.$

The results show that the incidence of both unemployment spells and unemployment rates rose during the recent economic crisis in Argentina (Table 9). The probability of being unemployed was 5.5 percent higher in May 2002 than in May 1999, holding all else constant. Regions have been affected differently. Compared to the city of Buenos Aires, unemployment in suburban Buenos Aires is higher, while the Northeastern region, Cuyo, and Patagonica are characterized by lower rates. However, the incidence of unemployment increased in greater Buenos Aires, and in the Northeast, Northwest, and Pampeana regions.

Turning to the characteristics of the individual, we find unemployment rates were higher for individuals with low levels of education. An extra year of education lowered the probability of unemployment by about 0.5 percent. Moreover, workers with less education were more likely to lose their jobs as the economic environment worsened, potentially because their low human capital made them less valuable to their firms. An extra year of education lowered the probability of becoming unemployed by approximately 0.3 percent. A similar argument can be made for younger workers and those with less working experience, who appeared to be more likely to be unemployed and to lose their jobs (note the negative relationship between age and unemployment rates, between age and transition into unemployment, and between years in an occupation and transition into unemployment).

Another finding is that while unemployment rates were higher among female workers by about 2 percent, the gender gap had vanished by the end of the period (see the coefficient for the interaction of gender and the May 2002 time dummy). This follows from the higher vulnerability to unemployment-measured as incidence of unemployment or the 
Table 9. Selected Logit Regression Results 1/

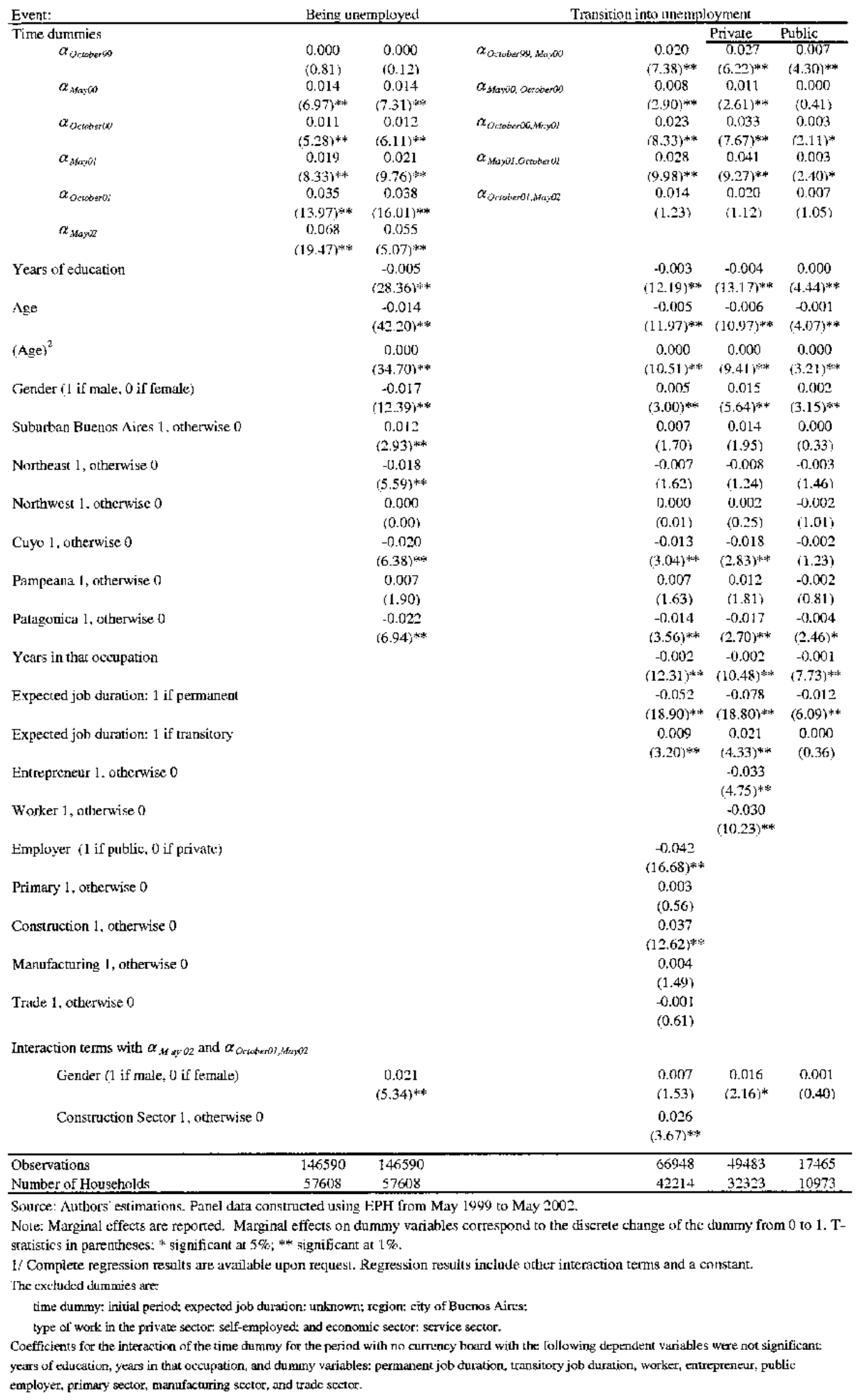


probability of becoming unemployed-among males, especially for the last period under andlysis. This result supports the notion of male-headed households' being more vulnerable to the crisis, as described in the previous section.

Stability of jobs differed across types of jobs. Consistent with the previous results on income changes, public employees were less likely to lose their jobs, and within the private scctor, adjustments in employment levels affected the construction sector the most, particularly during the period October 2001 to May 2002. Expected job duration also helps predict the probability of becoming unemployed: on average, permanent jobs are more stable than a series of temporary jobs during a macrocconomic crisis.

In the last two columns of Table 9 we present results on the probability of becoming unemployed for the private sector and the public sector separately. Within the private sector, we found that self-employed workcrs cxperienced higher transition rates into unemployment (about 3 percent more) than entrepreneurs and wage workers did. Moreover, since selfemployed individuals gencrally lack social protection schemes like severance payments or unemployment insurance, they faced serious difficulties in buffering unemployment shocks. The results for public sector employees are similar to the private sector employees, except that the effects are smaller in scale. For instance, while more-educated public sector workers were less likely to loose their jobs compared to less-educated public sector workers, the contribution of education was not as large as for private sector workers.

\section{Household Smoothing Mechanisms}

This section investigates the extent to which the labor income shock experienced by the head of household affected total household income. The following specification is used:

$$
\begin{aligned}
& \log \left(\frac{\text { Yhousehold }_{h, r, I}}{\text { Yhousehold }_{h, r, t-1}}\right)=\gamma+\alpha_{t-1, t}+\delta_{r}+\beta^{U} \cdot \log \left(\frac{\text { Yhead }_{h, r, t}^{\text {labor }}}{\text { Yhead }_{h, r, t-1}^{\text {laber }}}\right)+
\end{aligned}
$$

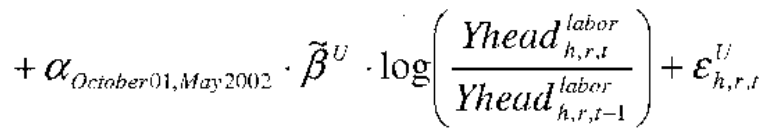

where $\alpha_{t-l, t}$ and $\delta_{r}$ are, respectively, time and regional fixed effects controlling for systemic fluctuations in the economy (that is, uninsurable shocks); and Yhead ${ }^{\text {labor }}$ denotes earnings of the head of household. ${ }^{19}$ An interaction term of $\operatorname{dog}\left(\right.$ Yhead $\left.{ }^{\text {labor }}\right)$ with the time dummy $\alpha_{O c o l, \operatorname{Mav}(2)}$ is included to test for differences in the responsiveness of household welfare to

\footnotetext{
${ }^{19}$ To avoid losing observations with zero labor income for the household head--which indeed are very informative about labor income shocks-we added one peso to both the labor income of the household head and to total household income.
} 
labor income shocks experienced by houschold heads after October 2001. Equation (4) is estimated using a random effects model.

The estimate for $\beta^{U}$, presented in Column 1 of Table 10, suggests that 32.2 percent of the head of household's labor income shock was not smoothed for each percentage change in his or her labor income. The unsmoothed part of the shock to the household head's earnings rose by 3.4 percent during the period between October 2001 and May 2002. This implies that the other sources of household income-such as other income sources of the head of household, or the labor income of the other household members-were less effective in protecting household welfare from changes in the income of household heads after October 2001.

Next, we focus on the evolution of the other income sources of the head of household during the period analyzed. The panel includes information on the following income sources: (1) pensions and other retirement, (2) rental and interest income, (3) profits and dividends, (4) unemployment insurance, (5) severance payments, (6) scholarships, (7) food subsidies, (8) private transfers by nonhousehold members, and (9) other. The question is whether these alternative income sources buffered the shock to the head of household's earnings, or if, on the contrary, they were positively correlated with the labor income shock experienced by the head of household. We estimated the following regression using a random effects specification:

$$
\begin{aligned}
\log \left(\frac{\text { Yhead }_{h, r, t}^{j}}{\text { Yhead }_{h, r, t-1}^{j}}\right)= & \gamma+\alpha_{t-1, t}+\delta_{r}+\beta^{U^{\prime}} \cdot \log \left(\frac{\text { Yhead }_{h, r, t}^{\text {labor }}}{\text { Yhead }_{h, r, t-1}^{\text {labor }}}\right)+ \\
& +\alpha_{\text {October } 01, \text { May } 2002} \cdot \tilde{\beta}^{U} \cdot \log \left(\frac{\text { Yhead }_{h, r, r}^{\text {labor }}}{\text { Yhead }_{h, r, t-1}^{\text {labor }}}\right)+\varepsilon_{h, r, t}^{j}
\end{aligned}
$$

where $j=1, \ldots, 9$ denotes each of the other income sources of the head mentioned above. Results are shown in Columns 3 through 11 of Table 10. We also estimated specification (5) for the summation of all the other income sources of the household head (Column 2, Table 10).

While estimates show no difference across regions in the evolution of each of the alternative income sources of the head of household, there are differences across periods. In particular, rental and interest income, unemployment insurance, and private transfers declined sharply during May 1999-October 2001. Regarding the beta coefficients, $\beta^{j}$, a negative estimate indicates a negative correlation between the labor income shock and the other income sources of the head of household. In other words, negative (positive) beta reflects smoothing (dis-smoothing) of the earning shock. The coefficients corresponding to Columns 2 through 11 are negative, indicating that during the time period analyzed, each of the other income sources of the head of household contributed to protect household welfare from the labor income shock. Note that for a percentage fall in labor income of the head of household, his or her nonlabor income rose by 25.2 percent. 
Food subsidies (Column 9), transfers from nonhousehold members (Column 10) and the category "other" (Column 11) were the most responsive in insulating the head of houschold's labor income shock.

Interactions of changes in the head of household's labor income with the October 2001May 2002 time dummy show that unemployment insurance, scholarships, and nonhousehold transfers were more negatively correlated with the labor income shock experienced by the head of household during the peak of the crisis; the opposite holds for severance payments. But on the whole, as Column 2 of Table 10 shows, the head of household's nonlabor income contributed to further buffer the shock to the head after October 2001.

We also investigated the role of alternative household income sources. Specifically, we examined the correlation between the earnings shock experienced by the head of household and the income of other members of the household,(Ymembers). The estimation results corresponding to specification (6) are presented in Table 11.

$$
\begin{aligned}
\log \left(\frac{\text { Ymembers }_{h, r, t}^{j}}{\text { Ymembers }_{h, r, t-1}^{j}}\right) & =\gamma+\alpha_{t-1, t}+\delta_{r}+\beta^{U} \cdot \log \left(\frac{\text { Yhead }}{\text { Yhead }_{h, r, t, t}^{\text {labor }}}\right)+ \\
& +\alpha_{\text {October } 0 \text { l, }, \text { May } 20102} \cdot \widetilde{\beta}^{U} \cdot \log \left(\frac{\text { Yhead }_{h, r, t}^{\text {labor }}}{\text { Yhead }_{h, r, t-1}^{\text {labor }}}\right)+\varepsilon_{h, r, t}^{j}
\end{aligned}
$$

where the superscript $j$ denotes either labor income (Column 1 in Table 11) or other sources of income (Column 2 in Table 11). Equation (6) is estimated using a random effects model. As before, "other" sources of income consists of the summation of pensions, other retirement, rental and interest income, profits, dividends, unemployment insurance, severance payments, scholarships, food subsidies, and private transfers by nonhousehold members.

Although the labor income of other members did not serve to smooth the shock to labor income of the head of household, the nonlabor income of other members did serve to buffer the shock after October 2001. The positive correlation between changes in the head of household's labor income and changes in the labor income of other members (Column 1 in Table 11) reflects that work prospects are being affected by similar factors. The interaction term of the shock to the household head's earnings and the time dummy, $\alpha_{\text {Octobero1,May02, }}$ indicates that the nonlabor income of other members was more effective in insulating the household income from the shock to the head of household's earnings during the peak of the crisis (Column 2 in Table 11).

Extremely poor households found it harder to buffer a shock to the labor income of the household head. Additional insight regarding the economic environment and household accessibility to the mechanisms to smooth income shocks is provided by testing for differences in the responsiveness of household income to the head of household's labor income shock across groups in the population. In particular, attention was given to the 
poorest households. We used a dummy for households categorized as the poorest and included it in regression (5) as a constant and also interacting with the head of household's labor income shock. Results are presented in Column 1 of Table 12. Column 1 shows that for extremely poor households, the unsmoothed fraction of the shock to the household head's labor is about 0.15 larger than for the rest of households. We also tested for differences in the performance of the other income sources of the head of household (Columns 2 through 11 in Table 12). We did not find a significant gap in the responsiveness of the summation of all the other income sources of the head of household (Column 2). However, while several income sources (pensions and other retirement; rental and interest income; dividends; unemployment insurance; and severance payments) protected the average household better, scholarships and the category "other" were more efficient in buffering the head of household's labor income shock among those households in extreme poverty.

To conclude, it should be emphasized that households, even those that are not extremely poor, are unable to perfectly smooth shocks. Therefore, social intervention via direct transfers can be useful mechanisms to assist households during macroeconomic crises. Given the high unemployment rate and the fact that vulnerable groups are likely to participate in the informal sector, transfers should not necessarily be tied to the labor market. Mechanisms used by households to cope with income shocks should be strengthened. There are already several such programs in place in Argentina (see Box 1). However, for the interventions to be targeted properly, programs should be evaluated on a routine basis. Those that prove to be ineffective in increasing household welfare, for instance via increased earnings, reductions in poverty, improved access to the labor market, or better education and health of children, should be discontinued and funds be reallocated to programs that do work. Finally, an optimal policy cannot ignore that some of the smoothing channels households engage in, such as changes in the labor force participation of household members, including children, are costly, or suboptimal. 
Table 10: Smoothing Estimation Results 1/

Responsiveness of the Other Income Sources of the Head to Fluctuations in Labor Income of the Head

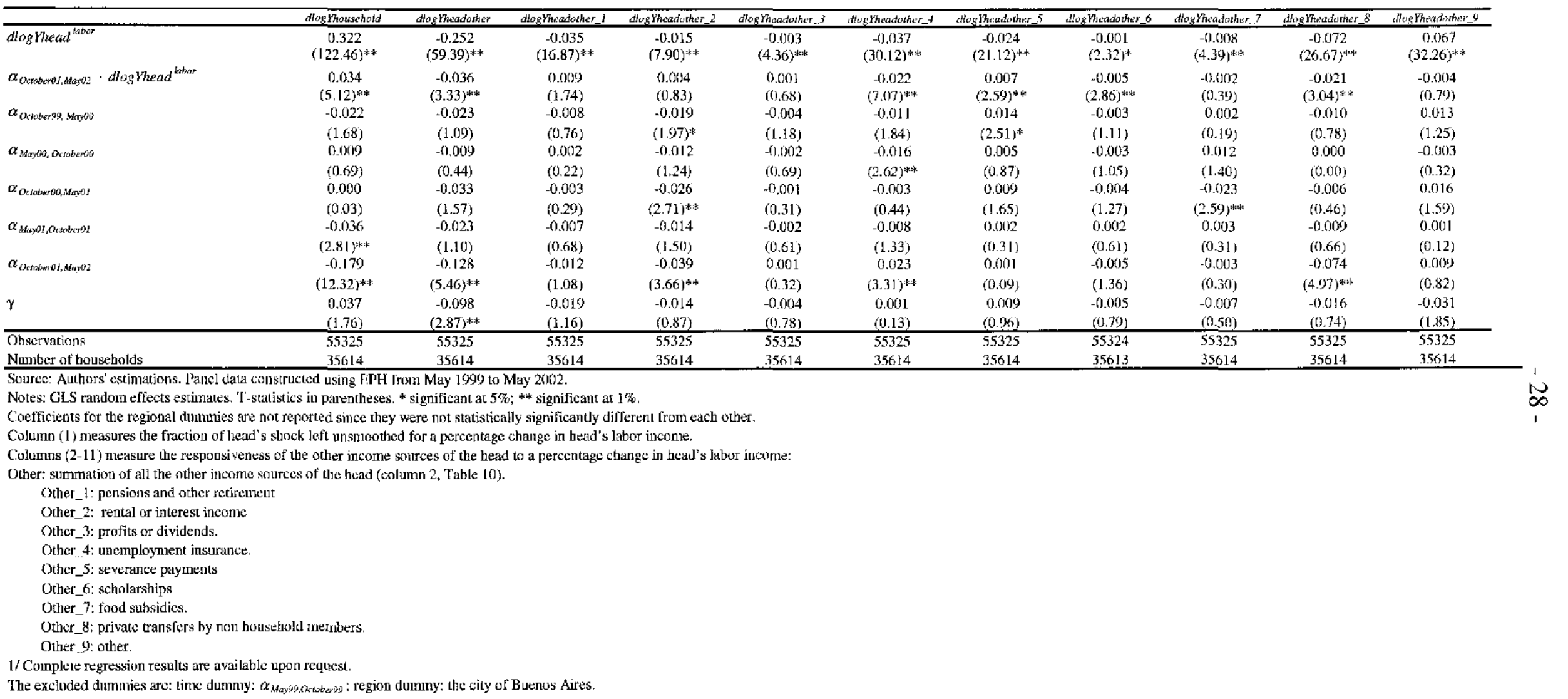


Table 11: Smoothing Estimation Results 1/

Responsiveness of the Income of the Other Adults to Fluctuations in Labor Income of the Head

\begin{tabular}{|c|c|c|}
\hline & 1 & 2 \\
\hline & dlogYmembers ${ }^{\text {tabor }}$ & dlogYmembers ${ }^{\text {oh her }}$ \\
\hline \multirow[t]{2}{*}{ dlogYhead $^{\text {labor }}$} & 0.017 & 0.002 \\
\hline & $(2.77)^{* *}$ & $(0.41)$ \\
\hline \multirow[t]{2}{*}{$\alpha_{\text {octoberot.Maxi2 }} \cdot$ dlogYhead ${ }^{\text {labor }}$} & 0.016 & -0.026 \\
\hline & $(0.99)$ & $(2.451)^{*}$ \\
\hline \multirow[t]{2}{*}{$\alpha_{\text {October } 99 . \text { Mavon }}$} & -0.081 & -0.032 \\
\hline & $(2.62)^{* * *}$ & $(1.51)$ \\
\hline \multirow[t]{2}{*}{ 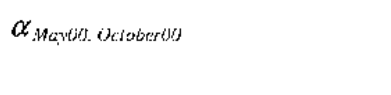 } & 0.050 & -0.032 \\
\hline & (1.64) & $(1.54)$ \\
\hline \multirow[t]{2}{*}{$\alpha_{\text {Octoberco,Aay Ot }}$} & -0.010 & -0.054 \\
\hline & $(0.31)$ & $(2.598)^{* *}$ \\
\hline \multirow[t]{2}{*}{$\alpha_{\text {Mayeri. Ortaberids }}$} & -0.097 & 0.006 \\
\hline & $(3.15)^{* *}$ & $(0.30)$ \\
\hline \multirow{2}{*}{$\alpha_{\text {OctoberOL, }, \mathrm{Ha}: 02}$} & -0.245 & -0.054 \\
\hline & $(7.08)^{* * k}$ & $(2.325)^{*}$ \\
\hline \multirow[t]{2}{*}{$\gamma$} & 0.167 & 0.109 \\
\hline & $(3.31)^{* * k}$ & $(3.188)^{* *}$ \\
\hline Observations & 55325 & 55325 \\
\hline Number of households & 35614 & 35614 \\
\hline
\end{tabular}

Source: Authors' estimations. Panel data constructed using EPH from May 1999 to May 2002.

Notes: GLS random effects estimates. T-statistics in parentheses. * significant at 5\%; ** significant at $1 \%$. $1 /$ Complete regression results are available upon request.

The excluded dummies are: time dummy: $\alpha_{\text {ikax } 99,0 \text { ctober } 99}$; region dummy: the city of Buenos Aires.

Regressions control for regional effects. 
Table 12: Smoothing Estimation Results-Change in Logarithms Specification: Average Household vs Extreme Poor Households 1/

Responsiveness of the Other Income Sources of the Head to Fluctuations in Labor Income of the Head

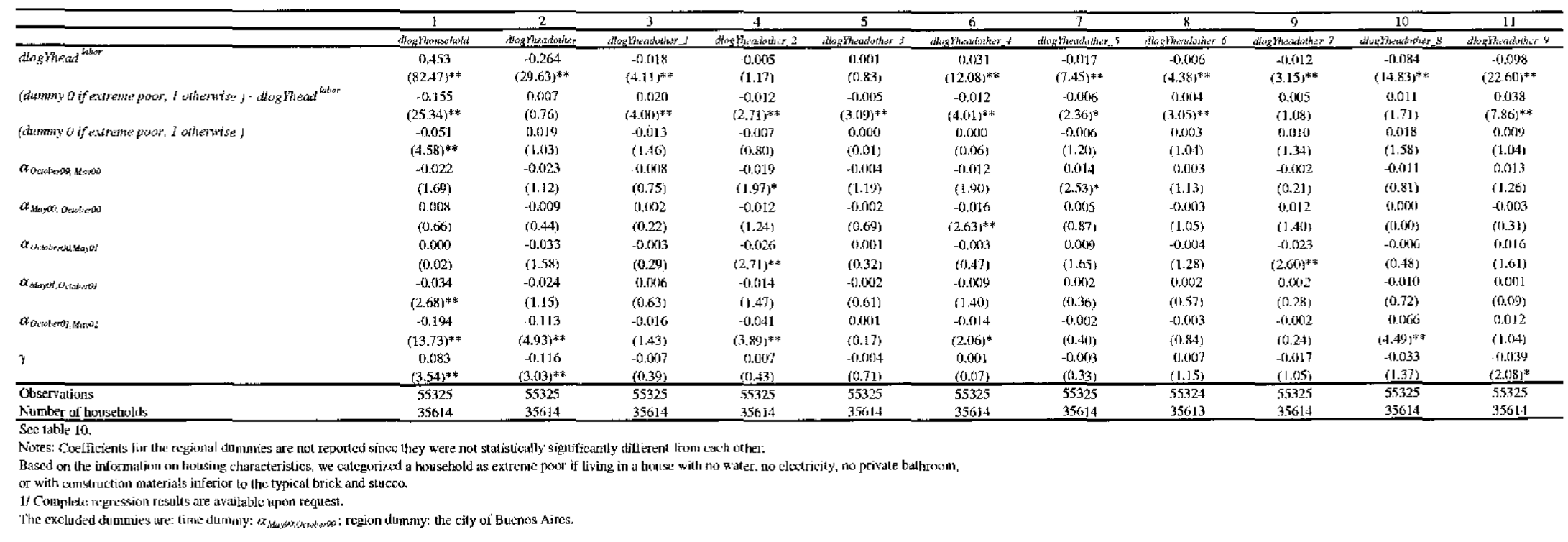




\section{Box 1. Argentina: Social Safety Nets}

Argentina's social welfare system is narrow and fragmented. The social safety net is made up of many small social assistance programs with overlapping national and provincial strategies. They serve various objectives: promoting rural development, improving housing and infrastructure, developing social and human capital, ensuring minimum food access, and providing assistance in the case of weather emergencies. However, there is yet no unified information system to prevent leakage of funds or use of competing programs by the same beneficiary. ${ }^{1}$ Most programs lack built-in evaluation mechanisms, and although eligibility criteria exist, it is unclear how funds are allocated when demand for benefits exceeds availability. In many instances, the distribution of benefits is subject to political influence by government officials.

In response to the crisis, the government introduced wide-ranging social emergency programs, focusing on providing financial assistance to support health, education, nutrition, temporary employment, income support and community development. Direct social assistance expenditures are estimated to have doubled as a share of GDP in 2002, and spending priorities were reoriented toward an identified core safety net program. The recently created National Council for Coordination of Social Policies (Consejo Nacional de Coordinacion de Politicas Sociales, under the Presidency) is currently developing a system of information, evaluation and monitoring of national social programs. Despite these efforts, key challenges continue to be the effective and proper implementation of safety nets, education, and health programs. ${ }^{2}$

In particular, the largest cash transfer program, Plan Jefes y Jefas de Hogar Desocupados, targets unemployed heads of households living with children under the age of 18 or handicapped family members. It is under the supervision of the Ministry of Labor, funded through the national budget and administered by municipalities. To receive a monthly cash allowance of $\$ 150$ transferred through the banking system, beneficiaries must perform activities for the municipality or for qualified NGOs. To be eligible, heads of households must certify that they are unemployed, that children in the household attend school and that they are vaccinated according to the national health program. Control of execution and transparency is the responsibility of municipal councils. The program reached over 1.5 million beneficiaries during 2002 , with a budget of nearly 1.3 billion pesos. ${ }^{3}$ However, the program does not have proper evaluation mechanisms to measure whether it has had significant effects on poverty, school attendance, or children's health, and does not have any built-in incentives so that heads of households go back to the labor market. Finally, the assignment of benefits is not devoid of political influence by local government officials.

The Programa Familias por la Inclusion Social provides cash transfers to poor families with schoolaged children, under the requirement of continued school attendance and health check-ups. This program is under the supervision of the Ministry of Social Development and administered by local governments. Potential households' beneficiaries must present information at local centers to be processed in a unified system. Participants must attend regular talks and present certified compliance with the requirements of the program. In this sense, it is similar to Mexico's Progresa. ${ }^{4}$ However, unlike Progresa, qualified applicants are not randomly selected to participate in the program, preventing the application of the best evaluation mechanisms. Benefits amount to $\$ 150$ per month and are transferred through the banking system.

1/ For exaniple, there is a food program for low income fanilies (Programa de Emergencia Alimentaria) under the supervision of the Ministry of Social Development and administered by provincial governments, which is not integrated with the food program for children in schools in rural and poor urban areas (Proyecto Comedores), under the Ministry of Education, or other food programs targeted to the old (Programa Probienestar de los Mayores), under the Ministry of Health. 2/ See IMF (2002).

3/ Source: SIEMPRO and INDEC.

4/ For details on Progresa, see for instance Corbacho and Schwartz (2002) and Hillman and Jenkner (2002). 
Box 1. Argentina: Social Safety Nets (concluded)

The Trabajar program provides short-term work at relatively low wages on socially useful projects in poor areas. The projects are proposed by local governments and NGOs, and workers can only join if recruited for an approved project. Projects last a maximum of six months and workers can switch to new projects after this period. The monthly wage is set low enough to ensure proper self-targeting from the pool of poor unemployed. Beneficiaries cannot receive unemployment benefits or participate in other similar programs. Trabajar was started in the mid 1990s and is currently in its third phase.

Trabajar III reached about 21,000 beneficiaries in March 2002 with a budget of $\$ 14$ million. ${ }^{5}$ Funding is transferred to local governments by the central government, leaving considerable amount of discretion to local government officials to allocate funds within the province. This has generated a fair amount of controversy in terms of how transparent these allocation mechanisms have been. The World Bank has performed studies to evaluate the impact of the second phase of the program. ${ }^{6}$ Main conclusions were that program participants are more likely to be poor than nonparticipants, and that it has generated significant income gains to participants. Studies have also found evidence of horizontal inequality in the allocation of funding across provinces, with equally poor districts recciving very different amounts of funding.

5/ Source: SIEMPRO and TNDEC.

6. See for instance Jalan and Ravallion (1999), Ravallion (1999b), and Ravallion and others (2001).

\section{SUMMARY AND CONCLUSIONS}

It stands to reason that households are not affected equally by macroeconomic shocks, such as economic crises or adjustment programs. However, little research has been done to identify which socioeconomic groups are more vulnerable to macro shocks, and the reasons why these groups suffer the most. In this paper, we have studied the effects of the macroeconomic crisis in Argentina between 1999 and 2002 with the aim of (1) identifying households that have been more vulnerable to the crisis, (2) investigating whether employment in the public sector and government spending served to decrease vulnerability, and (3) understanding mechanisms used by households to smooth the effects of the crisis.

Both poverty and income inequality increased over the 1999 to 2002 period, particularly between October 2001 and May 2002. In fact, individuals in the poorest decile of the income distribution experienced the largest declines in personal income. This result was even more pronounced during the period October 2001-May 2002-when per capita household income of the poorest decile collapsed by 41 percent compared to a 23 percent decline in the per capita household income of the richest decile-indicating that the relative vulnerability of poorest groups increased during the peak of the crisis.

The regression results suggest that household vulnerability was higher for households whose head was less educated and employed in the private sector versus the public sector, particularly in construction. In fact, households headed by public sector employees experienced a 4 percent smaller decline in income when compared to households headed by private sector employees, and this difference increased to 12 percent between October 2001 and May 2002. Larger households, those with more children, and those with a higher 
proportion of working members showed greater declines in income. In terms of the role of public sector expenditures, we found that households in provinces with higher public spending appear to be more vulnerable, particularly in provinces with high spending on wages and low capital expenditure. Interestingly, it seems that households in provinces that spent more on wages were on average more vulnerable, although public sector employees were better off. This suggests that provinces that allocated a large share of expenditures to wages had lower ability to assist households in the event of the crisis, given that it is difficult to reduce public wages in the short run to increase expenditures that may be better targeted to the most vulnerable groups.

Turning to the transmission channels of macroeconomic shocks to individuals, we focused on changes in the employment status of individuals. The results show that both the incidence of unemployment spells and unemployment rates rose during the recent economic crisis. Unemployment rates were higher for individuals with low levels of education, while job stability differed across types of jobs. Consistent with the previous results on income changes, public employees were less likely to lose their jobs, and within the private sector, adjustments in employment levels affected the construction sector the most, particularly during the period October 2001 to May 2002. Self-employed workers experienced higher transition rates into unemployment than entrepreneurs and wage workers did. Moreover, since self-employed individuals generally lack social protection schemes like severance payments or unemployment insurance, they faced serious difficulties in buffering unemployment shocks.

Last, we found evidence that households were unable to smooth shocks perfectly, especially households living in the poorest conditions. While estimates present no difference across regions in the evolution of alternative income sources, rental and interest income, unemployment insurance, and private transfers declined sharply on average as a result of the economy-wide shock. Finally, although several income sources (pensions and other retirement; rental and interest income; dividends; unemployment insurance; and severance payments) protected the average household better, scholarships and other transfers were more efficient in buffering the head of household's labor income shock among households in extreme poverty.

These results highlight the conclusion that social intervention can be useful to assist households in the event of a crisis. In particular, there is room for increasing the outreach of social safety nets. Public works programs (which can promote employment and capital investment leading to growth, and, therefore, lower vulnerability) can be especially useful. Direct transfers to the most vulnerable households could also be considered, although this should not be tied to the labor market since those more vulnerable are likely to participate in the informal sector. Finally, there is need to strengthen mechanisms households use to cope with shocks, such as through greater labor market flexibility allowing easier access to jobs. Argentina has a number of such programs in place, but there is still significant work to be done in this area. There is great need for better coordination among different governmental agencies providing social assistance to prevent program overlap, waste of funds, and abuse by beneficiaries. For social safety nets to be effective, proper targeting and transparency in 
allocation mechanisms-devoid of political interference-must be ensured, so that funds truly reach those that need them the most. Also, programs must be evaluated routinely using statistical techniques, and those programs that prove to be useful should be expanded while others should be discontinued. In addition, it is critical that good incentives be provided for heads of households to continue the search for employment and not rely on social assistance on a continuous basis.

Our analysis can be extended in several directions. By exploiting the data for households present in the sample for four consecutive surveys, we could trace the impact of negative income and employment shocks for more than one period and identify the characteristics that could help to reverse negative trends in welfare. Additionally, we could study the determinants of poverty and model the transition into poverty. Should more detailed data on public spending become available, further investigation on the impact of public social programs would be warranted, to better disentangle the effects of public spending on houschold vulnerability. Also, more analysis on the effects of household composition could address potential endogeneity in the result that larger households may experience larger income declines. Finally, the cffects of firm composition could be studied, to gain insight on whether targeted credit programs, for instance to small firms, could serve as an additional instrument to assist heads of households employed in these firms to cope with the effects of macroeconomic crisis. 


\section{References}

Agénor, Pierre-Richard, 2002, "Macroeconomic Adjustment and the Poor: Analytical Issues and Cross-Country Evidence," Policy Research Working Paper No. 2788 (Washington: World Bank).

Albornoz, Facundo, and Diego Petrecolla, 1996, "Medidas alternativas de la pobreza por ingresos para el Gran Buenos Aires, 1980-1995," Económica (Argentina), Vol. 42, No. 1-2, pp. 1-28.

Altimir, Oscar, 2001, "Long-Term Trends of Poverty in Latin American Countries," Estudios de Economía, Vol. 28 (June), pp. 115-55.

Alvarez, Fernando, and Stephen P. Zeldes, 2001, "Reducing Inflation in Argentina: Mission Impossible?" Educational Case Study. Available via the Internet: http:/www.gsb.columbia.edu/faculty/szeldes/Cases/Argentina/introduction.htm

Arnaudo, Aldo, and Buraschi, Marta, 1999, "Dos políticas para enfrentar una crisis: El Caso de México y Argentina," Economica (Argentina), Vol. 45, No. 4, pp. 317-46.

Asdrubali, Pierfederico, Bent E. Sørensen, and Oved Yosha, 1996, "Channels of Interstate Risk Sharing: United States 1963-1990," Quarterly Journal of Economics, Vol. 111 (November), pp. 1081-110.

Bonari, Damián, and Leonardo Gasparini, 2002, "El Impacto Distributivo de la Política Social en la Argentina," Documento de Trabajo No. GP/12 (Buenos Aires: Dirección de Gastos Sociales Consolidados, Ministerio de Economía).

Caballero, Ricardo J., 2000, "Structural Volatility in Argentina: A Policy Report," IDB Working Paper No. 422 (Washington: Inter-American Development Bank).

Choueiri, Nada, and Graciela L. Kaminsky, 1997, "Has the Nature of Crisis Changed? A Quarter Century of Currency Crises in Argentina,” IMF Working Paper 99/152 (Washington: International Monetary Fund).

Corbacho, Ana, and Gerd Schwartz, 2002, "Mexico: Experiences with Pro-Poor Expenditure Policies," IMF Working Paper 02/12 (Washington: International Monetary Fund).

Cunningham, Wendy, and William F. Maloney, 2000, "Measuring Vulnerability: Who Suffered in the 1995 Mexican Crisis?" (Washington: World Bank).

Dercon, Stefan, 2002, "Growth, Shocks, and Poverty During Economic Reform: Evidence from Rural Ethiopia," paper presented at the IMF conference "Macroeconomic Policies and Poverty Reduction," Washington (March). 
Eble, Stephanie, and Petya Koeva, 2002, "What Determines Individual Preferences over Reform? Microeconomic Evidence from Russia," Staff Papers, IMF, Vol. 49 (Special Issue), pp. 87-110.

Frankenberg, Elizabeth, Duncan Thomas, and Kathleen Beegle, 1999, "The Real Costs of Indonesia's Economic Crisis: Preliminary Findings from the Indonesia Family Life Surveys," Labor and Population Program Working Paper Series No. 99-04 (Santa Monica, California: RAND Publications).

_- and others, 2002, "Economic Shocks, Wealth and Welfare," paper presented at the IMF conference "Macroeconomic Policies and Poverty Reduction," Washington (March).

Galasso, Emanuela, Martin Ravallion, and Agustin Salvia, 2001, "Assisting the Transition from Workfare to Work. A Randomized Experiment," Policy Research Working Paper No. 2738 (Washington: World Bank).

Garcia-Escribano, Mercedes, 2002, "Does Spousal Labor Smooth Fluctuations in Husbands" Earnings: The Role of Liquidity Constraints" (Ph.D. dissertation; Chicago: University of Chicago).

Glewwe, Paul, and Gillette Hall, 1994, "Poverty, Inequality, and Living Standards During Unorthodox Adjustment: The Case of Peru, 1985-1990," Economic Development and Cultural Change, Vol. 42 (July), pp. 689-717.

__ 1998, "Are Some Groups More Vulnerable to Macroeconomic Shocks Than Others? Hypothesis Tests Based on Panel Data from Peru," Journal of Development Economics, Vol. 56 (June), pp. 181-206.

Hillman, Arye L., and Eva R. Jenkner, 2002, "User Payments for Basic Education in LowIncome Countries," IMF Working Paper 02/182 (Washington: International Monetary Fund).

International Monetary Fund, 2001, "Argentina: Third Review Under the Stand-By Arrangement: Request for Waivers and Modification of the Program," Country Report No. 01/90 (Washington).

_ 2002, "Argentina: Selected Issues," Country Report No. 02/385 (Washington).

Jalan, Jyotsna, and Martin Ravallion, 1999, "Income Gains to the Poor from Workfare: Estimates for Argentina's Trabajar Program," Policy Research Working Paper No. 2149 (Washington: World Bank). 
Llach, Juan, and Lucas Llach, 1998, "Cancelando la Hipoteca: Hiperinflación, Reforma de la Economía, Empleo y Desempleo en la Argentina de los 90," IDB Working Paper No. 385 (Washington: Inter-American Development Bank).

Mckenzie, David, 2002, "Household Consumption in a Volatile Economy: Mexico 1984-98" (New Haven, Connecticut: Yale University).

Ravallion, Martin, 1999a, "Is More Targeting Consistent with Less Spending?" International Tax and Public Finance, Vol. 6, No. 3, pp. 411-19.

__ 1999b, "Monitoring Targeting Performance When Decentralized Allocations to the Poor are Unobserved," Policy Research Working Paper No. 2080 (Washington: World Bank).

— 2000, "Are the Poor Protected from Budget Cuts? Theory and Evidence for Argentina," Policy Research Working Paper No. 2391 (Washington: World Bank).

—_ and others, 2001, "Do Workfare Participants Recover Quickly from Retrenchment?" Policy Research Working Paper No. 2672 (Washington: World Bank).

Uribe, Martin, 1996, "The Tequila Effect: Theory and Evidence from Argentina," Discussion Paper No. 552 (Washington: Board of Governors of the Federal Reserve System, International Finance Division).

World Bank, 2001, "Argentina: Household Risk, Self-Insurance and Coping Strategies in Urban Argentina," Sector Report No. 22426-AR (Washington). 